University of Tennessee College of Law

Legal Scholarship Repository: A Service of the Joel A. Katz Law Library

UTK Law Faculty Publications

3-2012

Mobilization and Poverty Law: Searching for Participatory

Democracy Amongst the Ashes of the War on Poverty

Wendy A. Bach

Follow this and additional works at: https://ir.law.utk.edu/utklaw_facpubs

Part of the Law Commons 


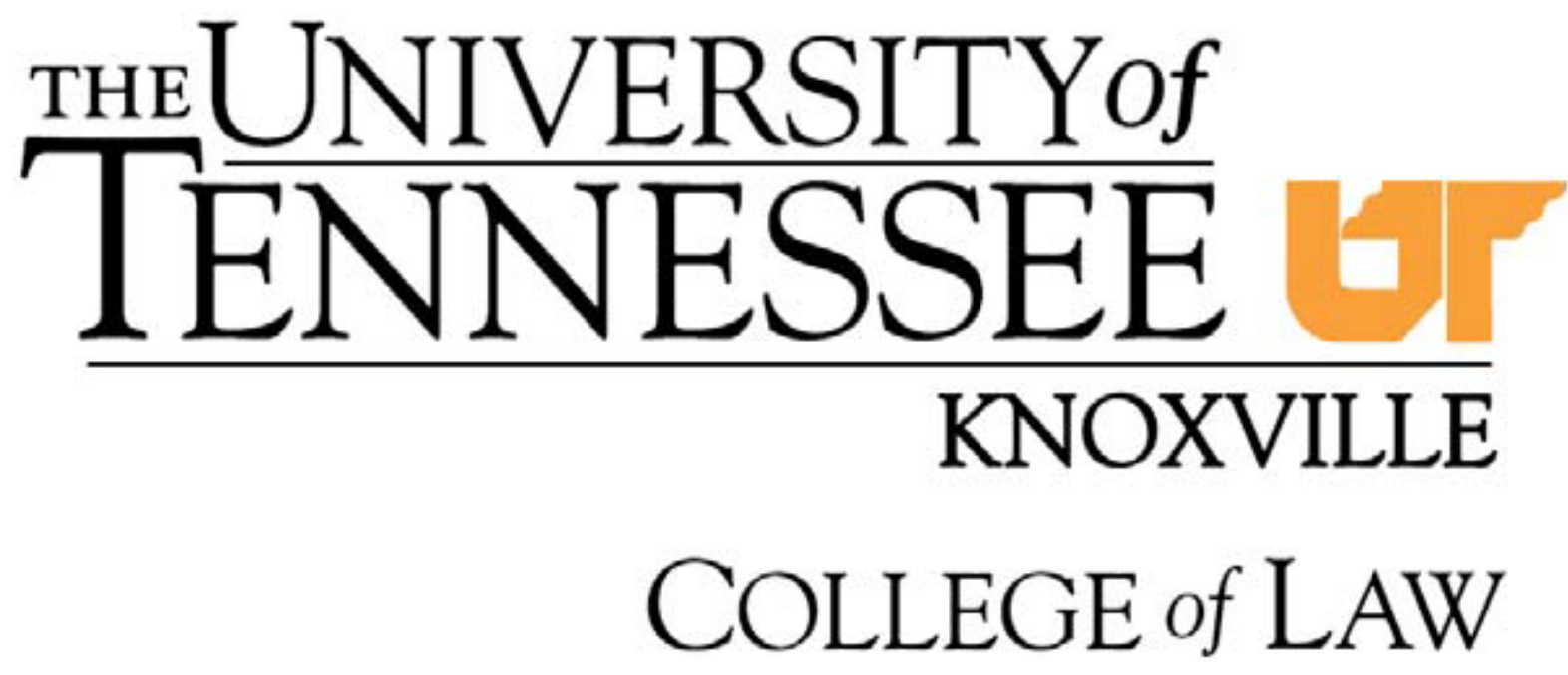

Legal Studies Research Paper Series

Research Paper \#180

April 2012

\section{Mobilization and Poverty Law: Searching for Participatory Democracy Amongst the Ashes of the War on Poverty}

Do not cite without author's permission

Copyright (C) 2012

Wendy A. Bach

This paper can be downloaded without charge

from the Social Science Research Network Electronic library at:

http://ssrn.com/abstract=2022020 


\title{
MOBILIZATION AND POVERTY LAW: SEARCHING FOR PARTICIPATORY DEMOCRACY AMONGST THE ASHES OF THE WAR ON POVERTY
}

\author{
Wendy A. Bach ${ }^{*}$
}

[P]overty is political; it is the product of decisions - made by the few rather than the many - about distribution of power, wealth, and opportunity. To fight poverty is to struggle for democracy. .

Robert Korstad and James Leloudis

To Right These Wrongs $2010^{1}$

Table of Contents

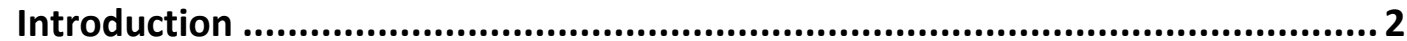

I. Rights On The Ropes: From Political Mobilization to Public Regulatory Law To

Disentitlement and Privatization...............................................................................6

II. From Welfare Reform to the New Poverty Agenda: Changing Governance

Structures and a Possible Return To Participatory Democracy.......................................11

III. Participatory Democracy and the War on Poverty .........................................18

A. Community Action and The Maximum Feasible Participation Mandate ...........18

B. Fair Service Provision, Opportunity Deprivation and Political Mobilization: The

Contested Aims of Participation in Community Action.................................................... 19

C. Implementing the Mandate Over Time.........................................................23

IV. Participation in Community Action: Extent and Impact ..................................27

A. Participation Overall: The View From the Period ..............................................28

V. Civil Rights Activism, Race Politics and Backlash ..............................................31

VI. Robust Participation At the Margins: North Carolina and Beyond .......................35

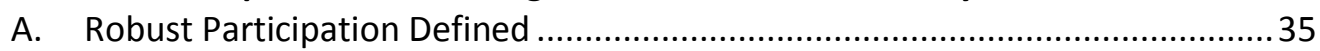

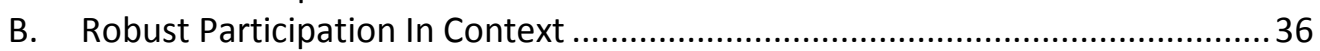

C. Robust Participation At the Margins: Durham, North Carolina .........................37

D. The Conditions Under Which Robust Participation Flourished: Some Lessons
}

From North Carolina and Beyond......................................................................... 47

VII. A Strategic Right to Participation: Some Possibilities, Implications and Areas for

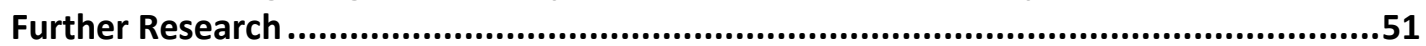

A. Law, Rights and Administrative Discretion ..................................................51

\footnotetext{
* Associate Professor of Law, University of Tennessee College of Law.

${ }^{1}$ Robert R. Korstad \& JAmes L. Leloudis, To Right ThESE Wrongs: The North CAROLINA Fund AND THE BATTLE TO END POVERTY AND INEQUALITY IN 1960S AMERICA 10 (2010).
} 


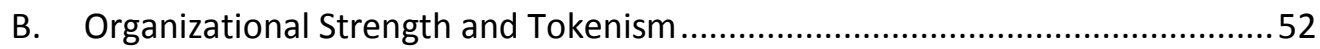

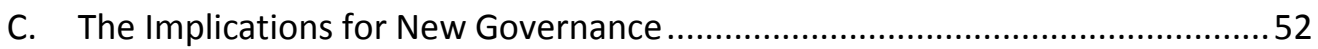

D. The Implications for Poverty Law.............................................................53

\section{INTRODUCTION}

In 1964, in the wake of Kennedy's assassination, President Johnson declared War on Poverty. In November of that year, Congress passed the Economic Opportunity Act of 1964. The Act included a wide range of service-based initiatives that had their roots in the structures and programs of the New Deal. In Title II, however, the act diverged significantly from the assumptions and programmatic structures of that past. Title II created the Community Action program, the purpose of which was, "to provide stimulation and incentive for urban and rural communities to mobilize their resources to combat poverty. . .." In Community Action Congress provided not a prepackaged service-based program like the Job Corps and training programs for youth and adults that compromised the rest of the act. Nor did it promote basic income and resource transfer programs of the kind that found their roots in the New Deal and were expanded and strengthened during the Great Society. Instead Community Action centered its hopes in large part on a grant making and local innovation process. As planned, that process had two essential elements: local innovation and participation. As to local innovation, communities were to mobilize resources and ideas and then receive federal funding to carry out their plans. As to participation, Title II mandated that Community Action Programs be, "developed, conducted, and administered with the maximum feasible participation of the residents of the areas and member of the groups served," or what would quickly be referred to as the "maximum feasible participation of the poor."3 As Sargeant Shriver, the Director of the Office of Economic Opportunity would describe it in 1966, in committing to maximum feasible participation, "the poverty program [staked] its existence on that same ideal upon which our nation gambled from the outset: Democracy."4

There is no question that today we are at a profoundly different historical and sociopolitical moment. Community Action was in large part born of and constituted by the realities of race and the growing commitment to federal control in the 1960s. The architects of Community Action included the participatory mandate largely to bypass profound resistance among southern politicians to any programs that might threaten the perpetuation of segregation and racial capitalism. ${ }^{5}$ In 1964, the mid to late twentieth century field of Poverty

\footnotetext{
${ }^{2}$ Publ. L. No 88-452, 78 Stat. 516. $\$ 201$.

${ }^{3}$ Annelise Orleck, Introduction: The War on Poverty from the Grassroots Up, THE WAR ON POVERTY: A NEW GRASSROOTS History 1964-1980 (2011)(ANNELISE ORLECK \& LiSA GAYLE HARIZRIJAN, EDS.) 3.

${ }^{4}$ OfFice of Economic Opportunity Exec. OfF. OF The President, COMMunity ACtion Program Memo No. 49 (1966) 2.

${ }^{5}$ See infra notes ___ and accompanying text. (Note to Articles Editor: In this draft I have not included jump cites or abbreviated citations. I prefer to reserve those tasks until I have completed any editing suggested by the journal in which the article is published).
} 
Law, with its mobilization and rights claiming strategies, was still to be created, attacked and profoundly eroded over the course of thirty plus years between the Great Society and the 1996 welfare reform act. Today, in emerging programs that I have elsewhere termed the New Poverty Agenda, ${ }^{6}$ we mostly hear less and less about rights but instead of social innovation, experimentation and rigorous evaluation. In the field of emerging governing structures however, participation and concepts of participatory democracy are again emerging. Today, in order for democratic experimentalism or new governance to function successfully, we are told that it is, "critical to ensure the broadest possible degree of stakeholder participation compatible with effective decision-making."7 Moreover, genuine stakeholder participation in all phases of the collaborative enterprise, crucially "including the setting of performance goals and metrics for evaluation ... [is put forward as having the potential to] . . "further democracy significantly more than traditional electoral means." ${ }^{~}$

This article posits that the emergence of elements of participatory democracy within new governing forms has created a strategic opportunity to increase accountability of poverty policy and furthers posits that a careful reexamination of the strategic wielding of the participatory opportunities within Community Action provides a framework to begin exploring this opportunity. ${ }^{9}$ Despite the wide historical chasm between 1964 and today, the rhetorical and structural similarities between Community Action and new forms of participatory democracy are striking. In short both posit that policy is ineffective and propose that the institution of a new, experimentalist participatory democratic form provides a key means to address those policy failures and spark innovation. The twin purported benefits are the same: policy will improve and participants will have richer opportunities to be effective and powerful democratic actors.

Given these similarities, the actual implementation of Community Action is instructive for at least two audiences. First, for those who ask whether new governance structures can effectively move some measure of programmatic control and political power into the hands of representatives of poor communities, this history answers quite clearly that, in their dominant form, new governance will fail to meet this objective. The design of Community Action invested far more than new governance in creating genuine participation by poor communities. And despite these efforts, in the main participation was fairly weak and

\footnotetext{
${ }^{6}$ Wendy A. Bach, Governance, Accountability and the New Poverty Agenda 2010 WISC. L. ReV 239.

${ }^{7}$ Grainne de Burca, New Governance and Experimentalism: An Introduction, 2010 at 741 WiSC. L. REv. 727 , 235.

${ }^{8}$ William H. Simon, New Governance Anxieties: A Deweyan Response, 2010 WISC. L. REv. 727, 730.

${ }^{9}$ The observation that there are remarkable similarities between new governance and community action has been made before. In particular, Tara J. Melish observed this similarity in Maximum Feasible Participation of the Poor: New Accountability, and a $21^{\text {st }}$ Century War on the Sources of Poverty. 22 Harv. Hum Rts. J. (2009). This article builds in Melish's fundamental observation about the similarities between the programs but focuses much more than Melish's on both how Community Action was actually administered and how primarily African American community activists successfully wielded the participatory mechanisms of Community Action to turn the program into something that served their needs.
} 
ineffectual.

But the overall failure of maximum feasible participation, quite like the weak nods to participation in today's new governing forms, does not suggest that these governing structures could not be wielded successfully, by activist communities, to accomplish their goals. Historically, while it is true that, for a wide range of reasons, Community Action largely failed as an experimental mechanism to recreate poverty policy, ${ }^{10}$ and also largely failed to transfer significant power to poor communities either in their ability to affect program content or to garner political power for their communities by virtue of the program, this was not universally true. At moments administrators and activists committed to realizing what this article will refer to as robust participation were able to wield the mechanisms of community action to shift significant programmatic control and political power into the hands of poor communities.

For poverty law practitioners and scholars, this particular aspect of the history of Maximum Feasible Participation provides a rich example of the means by which poor communities can wield a participatory democratic right. In this sense this history suggests that we, like our predecessors who faced a largely ineffectual participatory democracy structure, might engage in a version of what Scott Cummings has referred to as "constrained legalism," a strategic wielding of the mechanisms of the law, in this case a right to participation, to accomplish our goals while understanding the limits of the law to effectuate them. $^{11}$ In an historical manifestation of constrained legalism, the article describes the highly productive wielding of the right to participation in Community Action by poor communities. Despite the shortfalls of the program as a whole, this strategic wielding of the right did, at moments, steer Community Action dollars toward the needs and solutions articulated by those communities, and, perhaps more importantly, transferred some degree of political power to poor communities. For that reason, this history might suggest that we both consider reembracing participatory democracy as it arises, however weakly, in new governance forms and might suggest some means by which to accomplish that end.

To raise these questions and explore some answers, the article proceeds as follows. Section One frames current debates in poverty law and governance scholarship by tracing the trajectory of rights within Poverty Law from the Great Society, through Welfare Reform, and into post welfare reform initiatives that I have elsewhere termed the New Poverty Agenda. Section One begins with a description of the embattled conception of rights that remains in the wake of welfare reform. The section then turns to the War on Poverty and describes the

${ }^{10}$ See infra notes ___ and accompanying text.

${ }^{11}$ Scott L. Cummings, 120 HARV. L. REv. Forum 62 (2007). Cummings coined this term in a response to an article by Orly Lobel about the promise of law to effect change. Cummings described constrained legalism as that which, "strategically deploys law in a way that is neither utopian in its hopes for legal reform nor rejectionist in its dismissal of legal avenues of transformation." Id. at 63. 
central, but now largely lost role of participatory democracy and mobilization strategies during the War on Poverty. The article will ultimately argue that current policy may provide a small but significant opportunity to recenter these political strategies.

Section Two then describes the shift to the governing forms of the New Poverty Agenda and to new governance. The section highlights examples and characteristics of the New Poverty Agenda, new governance and the complicated relationship between the two. The Section also highlights a central struggle within new governance theory, namely the extraordinary difficulty of implementing meaningful participation in programs characterized by disproportionate political power among stakeholders.

Having laid this general historical context and framed current policy initiatives, Section Three then turns to the implementation of Community Action during the War on Poverty with a focus on the implementation of the mandate that programs be conducted with the maximum feasible participation of the poor. The section lays out the statutory and regulatory schema; the varying and often conflicting interpretations of the participatory mandate and the extensive and varied attempts by the administrative agency to ensure compliance with the participatory mandate. Of particular note is the commitment, by those administering the program, to using multiple structures and strategies to achieve meaningful participation and the controversial decision, by Congress and the agency, to fund independent activist groups as a means to render participation meaningful. The article will ultimately conclude that it was in moments when the agency funded independent community run groups that it was able to catalyze moments of robust participation.

Sections Four describes the limits of Community Action both in terms of its goal to fundamentally reorder the means by which communities address poverty and, more particularly, the overall failure to achieve participation as envisioned by the program's administrators. Section Five, however, presents an emerging consensus among historians that, although the poverty program did not fully live up to its framers vision, it did have a significant effect on the ability of communities to direct resources to their needs and to build organizations and develop political leaders, thus meeting some of the democracy building goals of the Community Action program and providing a fascinating context in which to look at the questions of what it might mean to realize significant participation and how to strategically wield participatory opportunities today.

To further explore the conditions under which participation flourished, Section Six turns to Community Action in Durham, North Carolina - an example of a moment when participation by poor communities appeared to be "robust" in the sense of both enabling the community to steer programs to their own needs and solutions and in its capacity to augment the political participation of previously a previously marginalized community. The Section begins by offering a working definition of robust participation and argues that in Durham and likely beyond Durham, in moments when participation was robust it correlated with two key 
factors, the first legal and the second socio-political. First, as to the legal factors, the presence of a participatory mandate and several actions, by administrators of the program to realize that mandate, were crucial. The law and the permeability of the administrative state to advocacy to realize a robust version of the participation was a crucial factor that allowed communities to move towards robust participation. Second, and probably most crucially, although much of new governance theory focuses primarily on legal structures, the history of the War on Poverty serves as a potent reminder that, despite the controversy, community based organizations and mobilization strategies by those organizations, played an essential role in rendering participatory opportunities robust. The article concludes, in Section Seven, with a discussion of the lessons to be gleaned from this study for both new governance and advocacy and suggests some paths toward future research and advocacy.

\section{Rights On The Ropes: From Political Mobilization to Public Regulatory Law To Disentitlement and Privatization}

Although the driving force of public benefits law, or what was historically termed welfare rights $^{12}$, has in the last several decades, largely abandoned its historic link with political rights and political mobilization, it is crucial to remember that these rights were, historically, central to theories of poverty law. In the wake of welfare reform, as Michael Katz has persuasively argued, U.S. poverty policy is largely driven by a conception of poor people as market rather than democratic actors. ${ }^{13}$ Today the doctrinal, statutory and regulatory rights associated with public benefits programs, to the extent that they still exist after welfare reform, are fairly described as a branch of "public regulatory law"14 the purpose of which is, "to make the most efficient and transparent application of whatever resource society allocates to a given purpose."15

\footnotetext{
${ }^{12}$ A full discussion of the welfare rights movement and its relationship to law is well beyond the scope of this article. For a rich discussion of that topic see Martha F. DAVIS, BRUTAL NeED: LAWYS AND the Welfare RigHTS MOVEMENT 1960-1973 (1993)

${ }^{13}$ Michael B. Katz, The Price of Citizenship: Redefining the American Welfare State 358 (2001). Similarly, as Alice O'Connor persuasively argued in her seminal study of twentieth century social science poverty research, [c]ontemporary poverty knowledge does not define itself as an inquiry into the political economy and culture of late twentieth-century capitalism; it is knowledge about the characteristics and behavior and, especially in recent years, about the welfare status of the poor. ALICE O'CONNOR, POVERTY KNOWLEDGE: Social Science, Social Policy, AND the Poor In Twentieth-Century U.S. History, 4 (2001).

${ }^{14}$ Lucy A. Williams, Welfare and Legal Entitlements: The Social Roots of Poverty, THE PoLiTICS OF LAw: A Progressive CritiQue 569, 581 (David Kairys, Ed. (1998)). As Williams further describes it, "[i]n hindsight ... we did not fully apprehend and mobilize the destabilizing potential of the welfare entitlement. . We generally envisioned an anti poverty strategy that deployed state intervention to redistribute income, focusing on the role of government in solving poverty through a top-down model of general taxation and transfer programs. We conceived our field as a branch of public regulatory law. . . . The right succeeded in reifying the distinction between wage labor and welfare (deserving and undeserving) and we lost the opportunity to undermine that distinction and expose the political construction of poverty and the conditions of low wage work. Id. at 580-81.

${ }^{15}$ David A. Super, The Political Economy of Entitlement, 104 Colum. L. Rev 633, 639 (2004).
} 
From the perspective of central architects of and community actors during the War on Poverty, as well as contemporary theorists of deepened democracy, ${ }^{16}$ however, a conception of the goal and measure of poverty policy centering exclusively on augmenting the market position of the poor is incomplete. ${ }^{17}$ There is no question that the political, mobilization focused strain of the War on Poverty was continually contested, largely the result of pressure from activists on the outside ${ }^{18}$ and fundamentally in tension with the dominant service and resource transfer oriented programs at the center of federal initiatives. Nevertheless, for key actors both inside and outside the administration, the strategic deploying of participatory democracy structures to transfer of political power to the poor was a central strategy and lay at the heart of many of the legal gains that arose from the War on Poverty. In multiple settings and through multiple structures, policy makers and activists centered these political goals. ${ }^{19}$

\footnotetext{
${ }^{16}$ For an extensive discussion of the theory of deep democracy or what Archon Fung and Erik Olin Wright have termed "Empowered Participatory Governance" see Wendy A. Bach Governance, Accountability and the New Poverty Agenda 2010 WISC L. REV. 239, 264-66 (citing Archon Fung and Erik Olin Wright, Thinking About Empowered Participatory Governance, DEEPENING DEMOCRACY: INSTITUTIONAL INNOVATIONS IN EMPOWERED PARTICIPATORY GOVERNANCE 4 (Archon Fung \& Erik Olin Wright eds.,( 2003)).

${ }_{18}^{17}$ See infra notes --- and accompanying text.

${ }^{18}$ See Peter Marris \& Martin Rein, Dilemmas of Social Reform: POVERTy and Community Action in THE UNITED STATES 260 (1973).

${ }^{19}$ The role of political power, political rights, and political activism in social welfare policy during the War on Poverty should not be overstated. The War on Poverty, broadly defined as federal interventions to address poverty undertaken from the early 1960s to the mid 1970s saw a significant expansion in federal initiatives, but the vast majority of that spending went to programs focused on service provision and a strengthening of the safety net. Michael Katz, In The Shadow of THE PoOrhouse: A SOCIAl History of Welfare in AMERiCA 254 (1986). From 1965 to 1972 , federal spending for social welfare increased from $\$ 75$ billion to $\$ 185$ billion dollars. Michael Katz, In The Shadow of the PoOrhouse: A Social History of Welfare In America 257 (1986). From 1960 to 1972, social welfare spending rose from 7.7 percent to 16 percent of GNP. MICHAEL KATZ, IN THE SHADOW OF THE POORHOUSE: A SOCIAL HISTORY OF WELFARE IN AMERICA 258 (1986). Launched during this time were an impressive new set of initiates, the most well known and long lasting of which include Medicaid, Head Start, and the Legal Services Corporation. See generally MichaEl KATZ, In The SHADOw of the Poorhouse: A Social History of Welfare in America 251-73 (1986). The War on Poverty, like the New Deal, did initiate a significant growth in spending and programs. For example, the years between 1930 and 1940 saw a vast expansion in the role of both federal and state government in providing aid to needy persons. The sheer growth in expenditures tells this story well. "In fiscal year 1913 all levels of government spent about $\$ 21$ million on public aid. By 1932, the amount had increased to \$208 million. In 1939 it jumped to $\$ 4.9$ billion.” Michael B. Katz, In The Shadow of the Poorhouse 246 (1986). As Katz describes it, "The New Deal had expanded vastly the role of the federal government and altered its relation to the states. States spend much more for welfare, which they administered more professionally. Government had assumed a degree of responsibility for economic security unprecedented in the nation's history." Id at 247. Nevertheless it did not diverge from some of the most disturbing aspects of prior policy. Most fundamentally, it failed to disturb the distinction at the heart of New Deal program between deserving and undeserving. In short the Social Security Act created Old Age Insurance and Old Age Assistance, the precursors of modern Social Security programs, for those who were perceived as deserving because they had worked. For needy single parents with dependant children, the Act created Aid to Dependant Children or ADC, which did little more than provide additional funds to states to fund widows pension programs. Walter I. TrattNer, From PoOR LaW TO Welfare STATE: A HistORY OF SOCIAL WELFARE IN AMERICA 290 (1999). This fundamental dichotomy would ultimately contribute to the dismantling of A.D.C in the 1980s and 1990s. MichaEL B. KATZ, THE PRICE OF CitizENSHIP 4
} 
The more politically focused agenda during the War on Poverty was linked to the Civil Rights Movement ${ }^{20}$ and to theories that poverty derived largely from a lack of political power in poor communities. This more political strain of the War on Poverty manifested itself in multiple ways. First, the Economic Opportunity Act of 1964 mandated that antipoverty Community Action Programs undertaken through the program promote, "the maximum feasible participation ... [of the poor]." ${ }^{21}$ As Sargeant Shriver, the Director of the federal agency charged with implementing Community Action described it in a 1966 memo reaffirming the agency's commitment to the participation, Community Action was at heart, "a [way] for democracy to come alive."22

Moreover, as discussed extensively below, in the hands of activists Community Action and Maximum Feasible Participation became a vehicle for mobilization in poor communities. The legal victories at the foundation of late twentieth century poverty law, King v. Smith ${ }^{23}$ and Goldberg v. Kelly ${ }^{24}$, were born of those campaigns. ${ }^{25}$ Organizations focused on community needs and community mobilization, largely funded through the Community Action program, used law and rights as a mobilization strategy. The idea of entitlement was leveraged, by lawyers and activists on the ground, to push vigorously back on discretionary policies that had previously kept African American women off the rolls. ${ }^{26}$ Lawyers working with activists in the Welfare Right Movement pursued legal claims on behalf of public assistance recipients. ${ }^{27}$

(2001). It architects also, like their historical precursors, largely ignored any role that uneven distribution of economic resources might play in creating or perpetuating poverty, choosing to focus largely on the purported cultural deprivation of the poor. MichaEl KATZ, In THE SHADOW OF THE POORHOUSE: A Social History OF WELFARE IN AMERICA 255 (1986). See also Marris and Rein at 113 - original allocation for Community Action was $\$ 315$ million.

${ }^{20}$ Michael Katz, In The Shadow of the PoORhouse: A Social History of Welfare IN AMERICA $252-54$ (1986)

${ }^{21}$ Robert R. Korstad \& JAmes L. Leloudis, To Right These Wrongs: The North CAROLINA Fund AND THE BATTLE TO END POVERTY AND INEQUALITY IN 1960S AMERICA 165 (2010).

22 Office of Economic Opportunity Exec. OfF. of The President, Community Action Program Memo No. 49 (1966) 15.

23392 U.S. 309 (1968)(holding that that Alabama 'substitute father' regulation requiring disqualification of otherwise eligible children from aid to dependent children if their mother 'cohabits' with man not obligated by Alabama law to provide support defines 'parent' in manner inconsistent with Social Security Act and is invalid).

24397 U.S. 254 (1970)(holding that procedural due process requires that pretermination evidentiary hearing be held when public assistance payments to welfare recipient are discontinued).

${ }^{25}$ For a full discussion of the organizing and litigation campaigns that led to King and Goldberg as well as other landmark decisions, See Martha F. Davis, Brutal NeEd: LAWYs AND the Welfare Rights MovemEnT 1960-1973, 56-69, 99-118 (1993).

${ }^{26}$ Lucy A. Williams, Welfare and Legal Entitlements: The Social Roots of Poverty, THE POLITICS OF LAW: A PROGRESSIVE CRITIQUE 569, 573-74 (David Kairys, Ed. (1998))(“. . . aggressive lawyering on behalf of poor people in the 1960s and 1970s removed many of the pervasive administrative barriers and subterfuges used to keep African American women off the roles.").

${ }^{27}$ Lucy A. Williams, Welfare and Legal Entitlements: The Social Roots of Poverty, THE POLITICS OF LAW: A Progressive CRITIQue 569, 574-75 (Organizations like, "[t]he National Welfare Rights Organization began an 
For example, fair hearings were a core component of the organizing strategy of the National Welfare Rights Organization (hereinafter "NWRO"). In New York City and across the country, the NWRO began a campaign to ensure that the welfare department provided increased benefits to recipients. Relying on provisions contained within the agencies' own manuals which seemed to guarantee the provision of grants for basic needs, organizers encouraged recipients to press their "rights" for "More Money Now." Central to this strategy was the use of fair hearings, a tool that organizers referred to as their "new weapon." This campaign had the result not only of ensuring the transfer of substantial funds into the hands of poor people, but it provided a means for organizers to recruit and maintain members who in turn wielded their collective strength in the interest of their communities. ${ }^{28}$

The lived idea, embodied within both some interpretations of "maximum feasible participation" and welfare rights organizing, that the governing mechanisms of U.S. poverty programs would provide a structural means to redistribute not just resources (a controversial enough idea) but power, led to a political firestorm. ${ }^{29}$ And that firestorm in turn led to the demise of central initiatives in the War on Poverty, and a near universal consensus still in existence today, among actors from a fairly wide political spectrum, that the War on Poverty failed. $^{30}$

Largely as a result of the tremendous strength of the political campaigns against the poor, social scientists, left leaning politicians and poverty law advocates staged a strategic retreat. As Alice O'Connor persuasively demonstrated over 10 years ago in work that remain relevant today, "contemporary poverty knowledge does not define itself as an inquiry into the political economy and culture of late twentieth-century capitalism; it [is instead] knowledge about the characteristics and behavior and, especially in recent years, about the welfare status of the

unprecedented campaign to get recipients the special needs to which they were entitled under existing regulations. Organizers saw the potential of the right to a pretermination hearing as a vehicle to empower recipients - to make them less afraid of losing subsistence benefits in retaliation for taking collective action." For the history of the Welfare Rights Movement see e.g. Felicia Kornbluh, The Battle fOR Welfare RIGHTS: POLITICS AND POVERTY IN MODERN AMERICA (2007).

${ }^{28}$ For an extensive discussion of the role of law and legal claims during the welfare rights movement and its relationship to claims for civil rights, see FELICIA KoRnBLUH, THE BATTLE FOR WELFARE RIGHTS 63-87 (2007). Although this article focuses on the origin of welfare rights, other poverty related rights claims were also formulated out of organizing work at the time. For am example see Thorpe v. Housing Authority of Durham, 393 U.S. 268, 271 (1969). For a discussion of the organizing and litigation that led to Thorpe see ROBERT R. Korstad \& JAMES L. Leloudis, To Right These Wrongs: The North CAROLINA Fund AND THE BATTLE TO END POVERTY AND INEQUALITY IN 1960S AMERICA 586-87 (2010).

${ }^{29}$ See infra notes ___ and accompanying text.

${ }^{30}$ For a discussion of the misrepresentation of the war on poverty as an unmitigated failure see e.g. MICHAEL B. KAtZ, The Undeserving PoOR: From The WAR On POVERTy to THE WAR ON Welfare 79-123 (1989). For a nuanced discussion of the general historical consensus that the War on Poverty failed and the need to rethink that narrative See Annelise Orleck, Conclusion The War on the War on Poverty and American Politics Since the 1960s, in THE WAR ON POVERTY: A GRASSROOTS History 450-56 (2011). 
poor." 31 In the face of this relentless attack, activist lawyers on the left were put on the defense. The project of Legal Services lawyers focused on poverty gradually became not primarily to support mobilization campaigns, ${ }^{32}$ but instead to protect "state intervention to redistribute income, focusing on the role of government in solving poverty through a topdown model of general taxation and transfer programs.",33

Although the story has been well told elsewhere, ${ }^{34}$ these retreats and pressures ultimately led to 1996 welfare reform law, which embraced a highly racialized set of stereotypes about poor people, ${ }^{35}$ abandoned entitlements, embraced privatization ${ }^{36}$ and devolved authority for policy to states and localities. Today, those who protect a rights or entitlements based theory within Poverty Law toil on profoundly limited ground and any mention of political participation rights within poverty law is, in many senses, a distant memory. However, significant trends within current policy indicate that there may again be a strategic opportunity to reinvigorate conversations about participatory democracy within poverty advocacy today.

31 Alice O’Connor, Poverty KnOwledge 4 (). See also Robert R. Korstad \& James L. Leloudis, To Right These Wrongs: The North CAROlina Fund AND THE BATTLE to END Poverty AND INEQUALITY IN 1960s AMERICA 8-9 (2010)(Politicians and intellectuals . . . worked aggressively to steer public debate away from the political economy of poverty to concerns about thee effectiveness of welfare and the behavior of the poor.").

${ }^{32}$ There are, of course, notable exceptions to the delinking of poverty law with organizing. In the last decade a variety of activist lawyers and scholars have committed themselves to Community Lawyering. An expansive discussion of law and organizing is outside the scope of this Article. However, some particularly important texts in the law and organizing field include: GERALD P. LÓPEZ, REBELLIOUS LAWYERING: ONE CHICANO'S VISION OF Progressive LaW Practice (1992); Sameer M. Ashar, Public Interest Lawyers and Resistance Movements, 95 CAL. L. REV. 1879 (2007); Scott L. Cummings \& Ingrid V. Eagly, A Critical Reflection on Law and Organizing, 48 UCLA L. REV. 443, 460-69 (2001); Scott L. Cummings, Critical Legal Consciousness in Action, 120 HARV. L. REV. Forum 62 (2007); Jennifer Gordon, We Make the Road by Walking: Immigrant Workers, the Workplace Project, and the Struggle for Social Change, 30 HARV. C.R.-C.L. L. REV. 407 (1995); Lucie E. White, To Learn and Teach: Lessons from Driefontein on Lawyering and Power, 1988 WIS. L. REV. 699 (1988). For an extraordinarily useful introduction to the literature of this field, see Loretta Price \& Melinda Davis, Seeds of Change: A Bibliographic Introduction to Law and Organizing, 26 N.Y.U. REV. L. \& SoC. CHANGE 615 (2001).

${ }^{33}$ Lucy A. Williams, Welfare and Legal Entitlements: The Social Roots of Poverty, THE POLITICS OF LAW: A Progressive CritiQue 569, 581 (David Kairys, Ed. (1998)).

${ }^{34}$ For an early and comprehensive discussion of the path toward that would lead to the Personal Responsibility Act see Michael B. KATZ, The Undeserving Poor: From the WAR ON Poverty To The WAR ON Welfare (1989).

${ }^{35}$ See e.g. See, e.g., Kenneth J. Neubeck \& Noel A. CaZenave, Welfare Racism: Playing The RaCE CARD

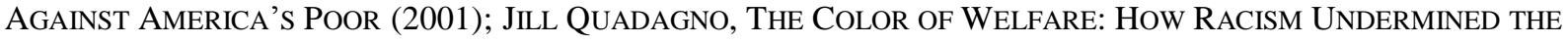
WAR ON POVERTY (1994).

${ }^{36}$ For discussions of the impact of privatization on welfare see Wendy A. Bach, Welfare Reform, Privatization and Power: Reconfiguring Administrative Law From the Ground Up, 74 BroOKLYN L. REV. 275 (2009); Matthew Diller, The Revolution in Welfare Administration: Rules, Discretion, and Entrepreneurial Government, 75 N.Y.U. L. REV. 1121, 1123-29 (2000). For a broader discussion of the shift to market theory in social welfare policy see Michael B. Katz, The Price of Citizenship: Redefining the AmericAn Welfare State (2001). 


\section{From Welfare Reform to the New Poverty Agenda: Changing Governance Structures and a Possible Return To Participatory Democracy}

Despite the sustained attack on the safety net leading up to welfare reform in 1996, there has been, in the last decade, a renewed, if limited, domestic conversation about how to alleviate poverty and a growing effort to design new interventions that might prove more successful than past efforts. ${ }^{37}$ At the same time, scholars and policy makers are focused on the creation of new and improved governing structures that fall generally under the rubric of "new governance" or "democratic experimentalism." For the purposes of this discussion what is most notable in these trends is an admittedly limited return, within both Democratic Experimentalism and the New Poverty Agenda, to the use of participation and experimentation in the creation of policy. This article suggests that this return to political participation renders the history of the War on Poverty particularly relevant to today's initiatives. In order to provide context for the more detailed historical discussion below, the following Section describes new governance or "democratic experimentalism," contextualizes some programs within emerging policy within this theory and then offers a range of critiques of democratic experimentalism from the field of Poverty Law and beyond.

\section{Democratic Experimentalism and Participatory Democracy: The Theoretical Framework}

The literature of new governing structures, termed variously "new governance," "the renew deal," and "democratic experimentalism" is wide ranging both in terms of the structures that fall within the definitional frames, the policy areas covered and the extent to which elements of governance theory are incorporated in emerging domestic and international policy. Internationally, examples abound, particularly in the European Union. ${ }^{38}$ Domestically, initiatives as diverse as community policing, ${ }^{39}$ special education ${ }^{40}$ environmental regulation, ${ }^{41}$ health care, ${ }^{42}$ housing, ${ }^{43}$ employment discrimination, ${ }^{44}$ financial regulation, ${ }^{45}$ occupational

\footnotetext{
${ }^{37}$ For a discussion of shifts in poverty policy after welfare reform see e.g. Wendy A. Bach, Governance, Accountability and the New Poverty Agenda 2010 WISC. L. REV. 239.

${ }^{38}$ For examples of New Governance forms in the European Union See e.g. multiple articles in Volume 22010 of the Wisconsin LAW REVIEW, a Symposium issue on comtaining articles that were presented at the Transatlantic Conference on New Governance and the Transformation of Law and GRAINNE DE BURCA \& JOANNA SCOTT EDS., LAW AND NEW GOVERNANCE IN THE EU AND THE US, 2006.

${ }^{39}$ Michael C. Dolf \& Charles E. Sabel, A Constitution of Democratic Experimentalism, 98 COLUM. L. REV. 2 (1998).

${ }^{40}$ Charles F. Sabel \& William H. Simon, Destabilization Rights: How Public Law in Litigation Succeeds, 117 HARV. L. REV. 1015 (2004). Simon? Or put in something that Sabol and Simon have done

${ }^{41}$ Bradley C. Karkkainen et al., After Backyard Environmentalism: Toward a Performance-Based Regime of Environmental Regulation, 44 AM. BEHAVIORAL SCIENTIST 692 (2000).

${ }^{42}$ Louise G. Trubek, New Governance and Soft Law in Health Care Reform, 3 IND. HEALTH L. REV. 137 (2006).

${ }^{43}$ Lisa T. Alexander, The Promise and Perils of "New Regionalist" Approaches to Sustainable Communities, 38 FORDHAM URB. L.J. 629 (2011).

${ }^{44}$ Susan Sturm, Second Generation Employment Discrimination: A Structural Approach, 101 COLUM. L. REV.
} 
safety, ${ }^{46}$ and poverty policy ${ }^{47}$ have been described as governing, or attempting to govern within the broad frameworks of new governance. Although the literature offers significant nuance as to definitional boundaries and structural requirements, at its heart New Governance stands in contrast to New Deal style top down rule making and is characterized by publicprivate collaboration, experimentation, localized program design, and the ability to test programs, jettison programs that are not effective and to promote and bring to a larger scale programs that are. In a new governance model, government acts not as a centralized rulemaker but as a facilitator of the experimentalist enterprise. Program improvements occur, over time, through the experimentalist, evaluative, and orchestration process and baselines are continuously reset as experimentation and evaluation lead to better and better results.

Crucially for those concerned with the means by which programs are rendered accountable to those they purport to serve, new governance theory offers mechanisms radically different from post New Deal style "old governance." In the field of Poverty Law, accountability, particularly in terms of ensuring non-discrimination and consistent provision of benefits, the law relies primarily on statutory and regulatory enforcement in administrative and judicial settings. In addition, freedom of information, sunshine laws, and notice and comment provisions subject the administrative state to various forms of public accountability. ${ }^{48}$

In a new governance field accountability, at least in the sense of creating programs that are responsive and effective, is said to flow from a very different set of mechanisms: participation by a broad range of stakeholders in goal setting and program design, rigorous experimentation and evaluation, and a continuous process of elevating standards so that no experimentation falls below the performance of the best performing experiment. So, for example, if district A's broadly participatory body creates a program that performs at meeting a goal at the rate of $80 \%$, other districts may continue to experiment so long as their experimental results do not fall below $80 \%$. The experimentalist enterprise is posited, therefore, to result in a continuous improvement in program design over time. ${ }^{49}$

458 (2001)

${ }^{45}$ Cristie Ford, New Governance in the Teeth of Human Frailty: Lessons from Financial Regulation, 2010 WIS. L. REV. 441 (2010).

${ }^{46}$ Orly Lobel, Governing Occupational Safety in the United States, in LAW AND NEW GOVERNANCE IN THE EU AND THE US 269 (Grainne De Burca \& Joanne Scott eds., 2006).

${ }^{47}$ Wendy A. Bach, Governance, Accountability, and the New Poverty Agenda, 2010 WIS. L. REV. 239 (2010).

${ }^{48}$ For a comparative discussion of the nature and utility of accountability structures in old and new governance forms, see Wendy A. Bach, Governance, Accountability and the New Poverty Agenda 2010 WISC. L. REV. 239, 257-69.

${ }^{49}$ This structure for continuous improvement is described in detail by Dorf and Sabol in explaining how a rolling best-practice system functions in fields such as environmental protection:

The administrative agency can ... use [the] connection between regulatory goals and efficiency to promulgate regulations in the form of rolling best-practice rules. Such rules require regulated entities to use processes that are at least as effective in achieving the regulatory objective as the best practice identified by the agency at any given time. In one variant, the current production method that creates the 
For the purposes of this article, the role of participation in creating democratic accountability is crucial and, as is discussed in Section III, remarkably resonant with articulations of program goals during the War on Poverty. From a new governance perspective, participation plays two crucial roles. First, it results in better more responsive programs and second it deepens democracy by conceptualization a far more robust role for for stakeholders in the creation of public policy. As Dorf and Sabol describe it in what is generally agreed to be a foundational article in the field, ${ }^{50}$

[Democratic Experimentalism aims] to change the reasons and evidence produced in public debate, and with them the conditions of participation in civil life, so that our disputatious democracy is made both more effective as an instrument of public policy and more faithful to its purpose of assuring the self-determination of free and equal citizens. ${ }^{51}$

A variety of scholars have waged a substantial critique of New Governance for its failure to achieve these participatory ideals in situations characterized by disproportionate power and history of subordination. Program in the field of poverty policy have been central to these critiques. However, before turning to those critiques, the following Section outlines the current and growing trend in using parts or all of new governance structures within poverty policy.

lowest level of risk is the standard all producers must meet (within a certain grace period), either by adopting those methods or devising equivalents. In another, polluters are pushed from the bottom of the heap rather than pulled toward the top.: The level of risk defined by the most hazardous operators defines a regulatory purgatory from which polluters must ascend (again within an agreed period); the acceptable minimum rises as the worst performers improve. In both cases, benchmarking establishes and periodically updates the standard to incorporate improvements, raising the ceiling in one case and the floor in the other.

Michael C. Dorf and Charles F. Sabol, A Constitution of Democratic Experimentalism 90 ColumBIA L. Rev. 267, 350-52 (1998).

${ }^{50}$ For a description of the foundational role of this article see Grainne de Burca, New Governance and Experimentalism: An Introduction, 2010 at 741 WISC. L. REV. 727, 228 note 5.

${ }^{51}$ Michael C. Dorf and Charles F. Sabol, A Constitution of Democratic Experimentalism 98 Columbia L. Rev. 267, 289 (1998). Dorf and Sabol also clearly posit that democratic experimentalism will serve to protect the vulnerable and create opportunities for enhanced democratic participation. See e.g. Michael C. Dorf and Charles F. Sabol, A Constitution of Democratic Experimentalism 98 Columbia L. Rev. 267, 407-08 (1998) ("If we are right in our assumptions regarding the efficacy of the participatory safeguards [in democratic experimentalism] . .., then arguably the vulnerable will be at least as well protected in an experimentalist regime as in one that makes their protection depend on evanescent legislative and judicial majorities."); William H. Simon, New Governance Anxieties: A Deweyan Response 2010 WISC. L. REV. 727, 736. ([T]o the extent that the process succeeds in meaningfully involving interested stakeholders, it affords a richer and more effective form of democratic participation on the relevant issues than is possible through voting in general elections."). 
2. New Governance Innovations in Poverty Policy: Experimentalism in Practice

In the field of poverty policy, programs that embrace some or all aspects of new governance theory and methodology abound. Noted examples in the literature include the role of residents in HOPE VI revitalization, the use Workforce Investment Boards within the Workforce Investment Act; the rise in target setting and public/private commissions in poverty policy, and a growing emphasis on experimentation in formulating poverty policy.

HOPE VI, enacted in 1992, substantially reformed the governance structures of public housing and has been put forward as epitomizing several important new governance features, including a set of mandates concerning participation of affected residents. ${ }^{52}$ For example, Hope VI Revitalization Grant Agreements mandate that residents have,

(1) substantial opportunities to provide input, advice, counsel, recommendations and opinions as the grantee plans and carries out its revitalization efforts; [and] (2) . . reasonable resources, as approved by HUD, for technical assistance, training, and capacity building to prepare affected residents to participate meaningfully in the planning and implementation of the Grantees revitalization efforts. ${ }^{53}$

Similarly, the Workforce Investment Act calls for the creation of local and state workforce investment boards that must bring together a wide variety of stakeholders, including clients, to govern state and local workforce policy. ${ }^{54}$ These broadly representative local boards negotiate performance measure with the state and then design programs to meet those performance goals. This structure is designed to and does in fact leave wide room for ongoing evaluation and experimentation.

52 See U.S. DEP'T OF HOUS. \& URBAN DEV., FY 2000 HOPE VI REVITALIZATION GRANT AGREEMENT, Art. XIII (B)(1)\&(2), available at http://www.hud.gov/utilities/intercept.cfm?/ offices/

pih/programs/ph/hope6/grants/revitalization/00/fy00_rev_grantagreement.pdf. Lisa Alexander, Stakeholder Participation in New Governance: Lessons from Chicago's Public Housing Reform Experiment, 16 GEO. J. LAW AND POL'y 117, 145 n. 152 (2009). See also Grainne de Burca, New Governance and Experimentalism: An Introduction, 2010 at 741 WISC. L. REV. 227, 231 (describing HOPE VI as discussed by Alexander as having "significant experimentalist features").

53 While HUD is recognized for placing limited mandates on applicants for funding under its programs, the NOFA (Notice of Funding Available) "does encourage applicants to develop a planning process, and a longrange plan that responds to some of local government law's failures to facilitate comprehensive solutions to interrelated problems." Lisa T. Alexander, The Promise and Perils of "New Regionalist" Approaches to Sustainable Communities, 38 FordHAM URB. L.J. 629, 653 (2011). Additionally, the NOFA defines activities that are eligible for this planning and reflection requirement. Id. at 653-54. For more discussion on mandates in practice and their significance for New Governance, see Id. at 633-36 and corresponding footnotes.

5429 U.S.C 2832 (2006). For discussions of the Workforce Investment Act and New Governance see e.g. Wendy A. Bach, Welfare Reform, Privatization, and Power: Reconfiguring Administrative Law Structures from the Ground Up. 74 BRoOKLYN L. REV. 275, 310-12; Orly Lobel, The Renew Deal: The Fall of Regulation and the Rise of Governance in Contemporary Legal Thought, 89 MINN. L REV. 342, 413-15 (2004). 
In addition, in a trend that I have elsewhere termed the New Poverty Agenda, a variety of jurisdictions and entities are introducing innovations in poverty policy that are governed, to greater and lesser extents, in ways consonant with new governance theory. In the wake of Hurricane Katrina and the John Edwards campaign there were a plethora of target setting initiatives and state and local poverty councils designed to analyze and reformulate poverty policy in those jurisdictions. To varying degrees these bodies required the participation of poor people in their deliberations and actions. Many of these jurisdictions, as well as several prominent national organizations, promote innovation and target setting as a central governance tool in emerging poverty policy. ${ }^{55}$

For example, New York City and recently the Obama administration have engaged in some of the most ambitious attempts at coordinated experimentation in poverty policy. In 2006, New York City Mayor Michael Bloomberg convened the Commission for Economic Opportunity to research and design a new poverty policy for the city. ${ }^{56}$ The Commission was composed of business and community leaders who were hand-selected by the Mayor's office. ${ }^{57}$ The Commission was charged with generating innovative poverty solutions that the city could execute without significant new expenditures and without reliance on state or federal action. It issued a report in 2006, and in 2007, Bloomberg opened a new executive office-The Center for Economic Opportunity (CEO) - to implement the recommendations of the report. ${ }^{58}$ Since that time CEO has overseen the implementation of a wide variety of programs, has issued multiple reports on its work, is regularly cited by other jurisdictions and in Washington as a model for new poverty policies. ${ }^{59}$ In recent years, CEO began administering federal grants to reproduce its programs in other jurisdictions. ${ }^{60}$ Additionally, efforts to reexamine how to measure poverty have taken hold in a variety of jurisdictions in an attempt to lay down new metrics for evaluating the effectiveness of poverty policy. ${ }^{61}$ Although CEO varies from some aspects of new governance in particular in the lack of a structural participatory mandate, it was conceived by a fairly broadly representative body, embraces rigorous evaluation and experimentation, and operates largely outside traditional, "old governance" regulatory structures.

Similarly, The Obama administration's Corporation for National and Community Service recently launched the Social Innovation Fund, which granted $\$ 50$ million to eleven "intermediary organizations" piloting programs to address poverty in the areas of Economic

${ }^{55}$ Wendy A. Bach, Governance, Accountability and the New Poverty Agenda 2010 WISC. L. REV. 239.

56. NYC CTR. FOR ECON. OPPORTUNITY, STRATEGY AND IMPLEMENTATION REPORT 1 (2007), available at $\mathrm{http}: / / \mathrm{www}$. nyc.gov/html/ceo/downloads/pdf/ceo_ 2007_exec_sum.pdf.

57. Id.

58. NYC Center for Economic Opportunity, About the Center, http://www.nyc.gov/html/ceo/html/home/home.shtml (last visited Mar. 23, 2010).

${ }^{59}$ CITES

60. See infra Part IV.

61. See infra Part IV.A. 
Opportunity, Youth Development and Health. ${ }^{62}$ The Social Innovation Fund gives grants to intermediary funding organizations, including New York City's CEO, ${ }^{63}$ which in turn provide grants as well as significant technical assistance to subgrantees. Crucial among the forms of technical assistance is a dedication to enabling the subgrantees to evaluate their programs along metrics set by both the intermediary and the social innovation fund. ${ }^{64}$ The emphasis on ongoing evaluation and the clear intent to use the program to identify and bring to scale successful models aligns this program, like NYC CEO, with significant experimentalist trends within new governance

While these programs, like many being discussed by new governance scholars, vary in the extent to which they incorporate new governance features, the overall movement to replace top down regulation with experimentation and the nods to participation, however minimal in some of these programs, create what I will argue below is, for poor communities and the advocates who seek to work in partnership with communities, a strategic opportunity. Before turning to that argument however, one must understand the real limitations of new governance to realize meaningful participation.

\section{Participation in Practice, the Limits of Experimentalism to Realize Deep Democracy}

New governance has been subject to a sustained and powerful critique by those committed to ensuring that law and regulatory structures provide accountability, particularly in contexts where the target of the law is serving the interests of marginalized or disempowered groups. Several scholars have argued that in situations characterized by disproportionate power and/or a long and entrenched history of subordination, new governing mechanisms have in fact been and are likely to be characterized by thin or no participation by affected communities and offer substantially less accountability to those communities than is offered by old governance structures. One example is offered by New York City's Center for Economic Opportunity,

\footnotetext{
${ }^{62}$ The Social Innovation Fund ("SIF") is intended to be a different approach to mobilizing people and businesses to come to the aid of low-income populations, a "'new way of doing business' for the federal government." SOCIAL INNOVATION FUND, http://www.nationalservice.gov/about/programs/innovation.asp (last visited Mar. 6, 2012). SIF was created under the 2009 Edward M. Kennedy Serve America Act, Id., which is aimed at creating innovating solutions to community challenges through bolstering individuals, nonprofits, and communities. For a description of the Social Innovation Fund grantees and subgrantees See http://www.nationalservice.gov/about/programs/innovation_grantees.asp\#3 (last visited December 8, 2011).

${ }_{63}$ CEO Awarded New Investment, Social Innovation Fund Grant by the Edna McConnell Clark Foundation, CENTER FOR EMPLOYMENT OPPORTUNITIES (Apr. 1, 2011), http://ceoworks.org/2011/04/ceo-wins-newinvestment-social-innovation-fund-award).

64 "One of the main goals of the Social Innovation Fund is to produce evidence on the effectiveness of the social programs it funds." Gary WalKer et Al., AbT Assoc., InC., SIF NAT'L Eval. Design: Summary of RECOMMENDATIONS 5 (May 26, 2011). In order to ensure that this is occurring, SIF intermediaries are given assessment tools by SIF by which to gauge their subgrantees. Id. Intermediaries themselves are assessed by SIF to determine what tools they themselves use to "define and measure capacity in their selection of community nonprofits." Id. at 8.
} 
which at least on the surface shares many of the crucial design elements that characterize new governance structures. Although the initial body that came together to launch the City's poverty experiments were broadly representative of government, business, academia and the non-profit sector, there were no poor people or organizations run by poor people offered a seat at the table. ${ }^{65}$ Other programs noted above, including Hope $\mathrm{VI}^{66}$ and the Workforce Investment $\mathrm{Act}^{67}$ have been similarly critiqued. Scholars have also engaged in a productive and challenging conversation about whether and how one might render new governance forms more accountable in situations characterized by disproportionate power with many concluding that it is profoundly difficult to use new governance structures in areas like poverty policy. ${ }^{68}$

The questions of whether to employ new governance mechanisms in poverty policy and, if so, how to do so in a way that renders the programs accountable are essential questions. This article, however, looks at these trends from a different stance. It takes as its baseline that, scholarly debates as to the relative utility of old and new governance mechanisms notwithstanding, the rise of experimentalism is a trend that is not likely to abate. It further posits that the existence of participatory opportunities within experimentalist endeavors might provide a useful tool for communities seeking to effect poverty policy. For this reason, looking carefully at how both administrators and communities wielded a participatory right to further the interests of poor communities yields crucial data for both those committed to deepening democracy in new democratic forms and to communities who might seek to wield new governing mechanism in ways that benefit their communities today. Specifically the article seeks to describe the circumstances under which poor communities and administrators attempted to use the right to participation in community action to 1 . steer programs in a direction that the community believed to be responsive to its needs and 2. transfer some additional measure of political power into the hands of leaders within those communities. In order to examine these questions in detail Section III through V provide an overall framework for understanding the participation in Community Action as well as its overall limitations and failures. Section VI then provides a detailed look at a robust implementation of participation in Durham, North Carolina. In Conclusion Section VII returns to the present and draws some lessons and directions for future research from this history.

${ }^{65}$ Wendy A. Bach Governance, Accountability and the New Poverty Agenda 2010 WiSC L. REV. 239.

${ }^{66}$ See Lisa Alexander, Stakeholder Participation in New Governance: Lessons from Chicago's Public Housing Reform Experiment, 16 GEO J. ON POVERTY L \& POL'Y 117 (2009)

${ }^{67}$ For an instance in which the participatory structures of the Workforce Investment Act initially failed to result in participation, see Wendy A. Bach, Welfare Reform, Privatization and Power: Reconfiguring Administrative Law From the Ground Up, 74 BROOKLYN L. REV. 275, 310, 12 (2009).

${ }^{68}$ See e.g. Douglas NeJaime, When New Governance Fails, 70 OHIO ST. L.J. 323 (2009); David A. Super, Laboratories of Destitution: Democratic Experiementalism and the Failure of Antipoverty Law, 157 U. PA. L. REV. 541 (2008); Lisa Alexander, Stakeholder Participation in New Governance: Lessons from Chicago's Public Housing Reform Experiment, 16 GEO. J. LAW AND POL'Y 117, 145 n. 152 (2009); Wendy A. Bach Governance, Accountability and the New Poverty Agenda 2010 WISC L. REV. 239. 


\section{Participatory Democracy and the War on Poverty}

From a pure statutory interpretation perspective, the requirement that Community Action programs be operated with the "maximum feasible participation of the residents of the areas and the members of the groups" left the administering agency, the Office of Economic Opportunity, with considerable room for interpretation. ${ }^{69}$ It was, at least in theory, possible to comply in ways that varied considerably from tokenistic representation to significant programmatic control by poor communities. During the short time span in which the agency attempted to implement the mandate, both the agency and the subject communities struggled to define the meaning of maximum feasible participation.

\section{A. Community Action and The Maximum Feasible Participation Mandate}

Title II of the Economic Opportunity Act of 1964 created the Community Action program, the purpose of which was to, "provide stimulation and incentive for urban and rural communities to mobilize their resources to combat poverty. ..."70 The act was administered on the federal level by the Office of Economic Opportunity and its regional offices. ${ }^{71}$ Under its auspices, Community Action Agencies (CAAs) were given an opportunity and funding to, "design almost any plausible program that might alleviate poverty." 72 CAAs were to be governed by policy making boards made up of, "broadly representative coordinating committees or poverty councils . . .."73 These poverty councils were charged with setting policy for the local CAP program and coordinating the services of local agencies. ${ }^{74}$ CAAs had the responsibility to, "conduct, administer and coordinate a wide variety of anti-poverty actions within a major political jurisdiction. ..."75 Although the extent of control by public officials varied both among CAAs during the period and across time, ${ }^{76}$ generally CAAs were, "established outside the political and administrative structure of local government."77

\footnotetext{
${ }^{69}$ See infra notes ___ and accompanying text.

${ }^{70}$ Publ. L. No 88-452, 78 Stat. 516. $\$ 201$.

${ }^{71}$ The OEO was created by virtue of the Economic Opportunity Act of 1964. Public Law 88-452, 78 Stat 503. Economic Opportunity Act of 1964 Section 601(a).

72 J. David Greenstone and Paul E. Peterson, Race And Authority in Urban Politics: Community PARTICIPATION AND THE WAR ON POVERTY 2 (1976).

73 J. David Greenstone and Paul E. Peterson, Race and Authority in Urban Politics: Community PARTICIPATION AND THE WAR ON POVERTY 3 (1976). For specific details on the requirements for board membership and board role, see generally OFFICE OF ECONOMIC OPPORTUNITY, COMMUNITY ACTION PROGRAM GUIDE (1965) and amendments to that guide in subsequent directives issued by the Office of Economic Opportunity.

74 J. David Greenstone and Paul E. Peterson, Race And Authority in Urban Politics: Community PARTICIPATION AND THE WAR ON POVERTY 3 (1976).

75 OfFice of Economic Opportunity Exec. OfF. OF The President, Community Action Program Memo No. 9-A (1967) 1.

${ }_{77}^{76}$ See infra notes ___ and accompanying text.

${ }^{77}$ David M. Austin, Resident Participation: Political Mobilization or Organizational Co-Optation?, 32 PuBLIC ADMIN. REV. 410 (1972).
} 
In the eyes of the administering agency, an ideal Community Action Programs was "broadly-based, organized on a community-wide basis, and involve[d] the coordination of a variety of antipoverty actions. . . [that embraced] components in all of the major service systems and [extended] to all of the major concentrations of poverty within the community."78 The CAAs were responsible for coordinating service programs in the geographic area that they served. In addition, in most large jurisdictions the CAA in turn often supported the creation of smaller neighborhood organizations the function of which was to engage in community based work and often to manage the implementation of CAA programs within their communities. ${ }^{79}$ By February of 1967 there were over a 1,000 Community Action Agencies in operation across the United States."

B. Fair Service Provision, Opportunity Deprivation and Political Mobilization: The Contested Aims of Participation in Community Action

The origin ${ }^{81}$ and purpose of the mandate that programs be conducted with "the maximum feasible participation of the residents of the areas and the members of the groups" 82 was, from the very beginning, highly contested. The contest over the meaning and scope of participation flowed from contests over the meaning of and solutions to poverty prevalent at the time. Interpretations of the mandate varied widely, from the fairly moderate view that participation focused only on equal service delivery to the much more radical view that participation meant that poor communities would, through Community Action, seize control of the poverty

\footnotetext{
${ }^{78}$ Office of Economic Opportunity, Community Action Program Guide (1965) 17. See also David M. Austin, Resident Participation: Political Mobilization or Organizational Co-Optation?, 32 PUBLIC AdMIN. Rev. 410 (1972).

${ }^{79}$ David M. Austin, Resident Participation: Political Mobilization or Organizational Co-Optation?, 32 PuBLIC ADMIN. REv. 411 (1972). In his study of Community Action in 20 cities, David Austin refers to these neighborhood based organizations as "target-area associations." Austin provides extensive information abou the composition, structure and activities of these organizations. For a tremendously interesting and rich discussion of the correlations between election, appointment and the substantive representation outcomes in various cities see J. David Greenstone and Paul E. Peterson, Race and Authority in Urban Politics: Community PARTICIPATION AND THE WAR ON POVERTY 166-99 (1976). For a discussion of the role and structure of neighborhood based community action agencies from the view of the administering agency, see OFFICE OF ECONOMIC OPPORTUNITY EXeC. OfF. OF THE PRESIDENT, COMMUNITY ACTION PROGRAM MEMO No. 9-A (1967) 5-7.

${ }^{80}$ Office of Economic Opportunity EXec. OfF. OF The President, Community Action Program Memo No. 9-A (1967) 1.

${ }^{81}$ The origin of this language is credited to Richard Boone, a key poverty advisor to President Kennedy who was profoundly influenced by the work of Ohlin and Cloward. Annelise Orleck, Introduction: The War on Poverty from the Grassroots Up, THE WAR ON POVERTY: A NEW Grassroots History 1964-1980 (2011)(ANNELISE ORLECK \& LISA GAYLE HARIZRIJAN, EDS.) 10.

${ }^{82}$ Public Law 88-452, 78 Stat 503. Economic Opportunity Act of 1964 Section 202(a)(3). See also RoBert R. Korstad \& JAMES L. Leloudis, To Right THESE WrongS: THE North CAROLINA Fund AND THE BATTLE to END POVERTY AND INEQUALITY IN 1960s AMERICA 165 (2010).
} 
program. $^{83}$

\section{Fair Service Provision}

For many governmental actors, the maximum feasible participation mandate, to the extent that it was initially noticed at all, ${ }^{84}$ meant little more than that programs would serve all members of any particular community. ${ }^{85}$ Daniel Patrick Moynihan, a then Junior Senator from New York and a congressional actor, for many decades, in federal poverty policy, wrote of Maximum Feasible Participation shortly after its demise that,

... the record, such as can be had, and recollection indicates that [maximum feasible participation] was intended to do no more than ensure that persons excluded from the political process in the South and elsewhere would nonetheless participate in the benefits of the community action programs of the new legislation. It was taken as a matter beneath notice that such programs would be dominated by the local power structure. ${ }^{86}$

From Moynihan's perspective the subsequent use of the mandate as a mobilization device was never intended by the program's designers and was the source of the program's demise. In fact, Moynihan laid the blame for the demise of any chance at winning a guaranteed minimum income at what he perceived to be an irresponsible use of the participation mandate. $^{87}$

\footnotetext{
${ }^{83}$ For an extensive and nuanced description of the intellectual foundations of the War on Poverty See MiCHAEL B KatZ, THE UndeSERVING POOR: From the WAR ON POVERTY TO THE WAR ON WELFARE 79-123.

${ }^{84}$ The Maximum Feasible Participation mandate was passed with little notice by relevant congressional committees. J. David Greenstone and Paul E. Peterson, Race and Authority in Urban Politics: COMMUNITY PARTICIPATION AND THE WAR ON POVERTY 5 (1976).

${ }^{85}$ Robert R. Korstad \& JAMES L. Leloudis, To Right TheSE Wrongs: The North CARolina Fund AND THE BATTLE TO END POVERTY AND INEQUALITY IN 1960S AMERICA 6 (2010) Annelise Orleck, Introduction: The War on Poverty from the Grassroots Up, THE WAR ON POVERTY: A NEW GRASSROOTS HISTORY 1964-1980 (2011)(ANNELISE ORLECK \& LISA GAYLE HARIZRIJAN, EDS.) 10.

${ }^{86}$ DANiel P. Moynihan, MAXIMUM FeAsible Misunderstanding 86-87 (1970). See also Robert R.

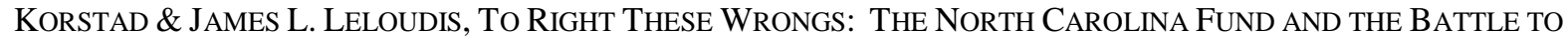
END POVERTY AND INEQUALITY IN 1960S AMERICA 6 (2010).

87 Daniel P. Moynihan, MaXimum Feasible Misunderstanding 99-100 (1970) Ultimately it appears that Johnson was most closely allied with a more conservative view of participation. See e.g. Guian A. McKee, "This Government is With Us": Lyndon Johnson and the Grassroots War on Poverty," THE WAR ON POVERTY: A NeW GRASSRoOTS History 1964-1980 (2011)(ANNELISE ORLECK \& LISA GAYLE HARIZRIJAN, EDS.) 31-62. For an analysis from Moynihan's era that differed substantially from Moynihan on this point see PETER MARRIS \& Martin Rein, Dilemmas of Social Reform: Poverty and Community ACtion in the United States 251, 259-60 (1973)("In reality, OEO could hardly have avoided the issue of citizen participation, whatever the legislative mandate and the risks of controversy. Wherever civil rights groups or neighborhood organizations could claim to speak for the ghetto, they were bound to demand control. Planning and demonstration programmes meant to them the white definition of black needs, and they had learned to expect little worthwhile from them. . . The OEO was surely right to believe that the days when poor people would passively accept
} 


\section{Opportunity Deprivation, Service Coordination and Experimentation}

A second, and quite strong view of the participatory mandate, and the view targeted by Moynihan in his attack on Community Action, Maximum Feasible Misunderstanding, drew directly on the theories Richard Cloward and Lloyd Ohlin and the experimentation of the Ford Foundation in its Gray Areas Project. In 1960 Cloward and Ohlin published Delinquency and Opportunity. In that seminal text Cloward and Ohlin argued that "widespread tendencies toward delinquent practices in the lower class" $" 88$ were caused by a mismatch between aspiration and opportunity. As one analyst of this theory described it, “ . . . multiple factors including lack of access to the political and economic systems, systematic racial discrimination, and ineffective social institutions ... prohibit rather than facilitate full participation in the larger society." 89 Opportunity Deprivation theory would come to underlie the Ford Foundation's Gray Areas project in the 1960s, a program that is widely acknowledged as a precursor to Community Action. ${ }^{90}$ Cloward and Ohlin described the widespread failure of the institutions of poor communities, schools, and social welfare agencies to meet the needs of the poor. Poor communities and poor people, in their view, possessed all the same aspirations as others, but the institutions of their communities systematically barred them from realizing those opportunities.

The Gray Areas project, in turn, translated these theories into an experimental program in which new community organizations, structured to include the participation of the poor in their governing structure, would entirely revamp American poverty policy. In the Gray Areas project,

... [F]oundation funds were made available not just to help with ongoing work or to provide needed services that were not available, but rather to transform the political and social life of the community through new community organization. ${ }^{91}$

Through the work of the new community agency, which was to become Community Action, ${ }^{92}$ cities and rural areas would, look, "beyond old and fixed ways of doing things, [and] invent

what they were given were numbered everywhere.").

${ }^{88}$ Richard A. Cloward AND Lloyd E. OHLin, DELINQUENCY AND OPPORTUNiTy: A THEORY OF DELINQUENT GANGS 106 (1960).

${ }^{89}$ StePhen M. Rose, COMmunity ACTION Programs: THE RELATIONSHIP BetweEn INITIAL CONCEPTION OF THE POVERTY PROBLEM, DERIVED INTERVENTION STRATEGY AND PROGRAM IMPLEMENTATION 97 (1970).

90 The dominance of Opportunity Theory in the theorizing of the War on Poverty is clearly demonstrated in the use of the term "opportunity" in the name of the statute creating the program. Annelise Orleck, Introduction: The War on Poverty from the Grassroots Up, The War ON POVERTY: A NEW GrassROOTS HistORY 1964-1980 (2011)(ANNELISE ORLECK \& LISA GAYLE HARIZRIJAN, EDS.) 10.

${ }^{91}$ DANIEl P. Moynihan, MaXimum FeAsible Misunderstanding 36 (1970).

${ }^{92}$ For a discussion of the relationship between the Ford Foundation and Community Action see e.g. MICHAEL B. KatZ, In The Shadow of The PoOrhouse: A Social History OF Welfare in AMERICA 255. 
and evaluate new approaches in education, housing, employment, legal services and welfare." 93 At the same time, and crucially for this theory, participation by affected communities would not only lead to the creation of services and programs that met needs of those communities but it would also, in the eyes of its designers "overcome anomie and social disorganization by energizing previously apathetic and disaffected poor people to act on their behalf." 94

\section{Race, Mobilization and the Civil Rights Movement}

A final view the participatory mandate arose directly from those involved in political mobilization at the time. The mobilization-centered view of Maximum Feasible Participation was linked to both the Civil Rights and the Labor Rights Movements. Walter Reather and Jack Conway, both central figures in the Office of Economic Opportunity and both closely associated with the labor movement, "saw in the War on Poverty an opportunity to institutionalize a labor civil rights coalition capable of reversing the [political alliance of conservative republicans and segregationalist southern democrats] and reinvigorating a social democratic agenda." 95 At the heart of this position, espoused by both some administrators of Community Action and advocates on the outside, was the belief that, in order to address poverty, the poor must acquire power as well as money. In this view,

... poverty had a political as well as an economic dimension. Low-income citizens required not only improved services for individual clients; it was also necessary to mobilize community groups and to develop new political elites that could effectively articulate group interests. ${ }^{96}$

Recent historians of the War on Poverty describe a related but more bottom up perspective on participation. In these histories, participation and Community Action were central tools, used by poor communities advocating on behalf of a wide range of communities of color, to continue the work of the Civil Rights movement and address the real needs of their

93 Michael B Katz, The Undeserving Poor: From the War on Poverty to the War ON Welfare 82. (1989)(quoting Paul N. Ylviskar, "A Foundation Approach to City Problems," in American Community Development, Preliminary Reports by Directors of Projects Assisted by the Ford Foundation in Four Cities and a State at 5). Clearly missing from the analysis espoused by the Ford Foundation was any mention of structural economic inequality or the need to create jobs. As Katz describes it, the framers of the War on Poverty relied on economic growth to create jobs and therefore focused on service delivery. As he frames the thinking at the time, "[b]ecause growth would stimulated demand and enlarge the available rewards, the readication of poverty required no painful reallocation of money . . . ." MichAEL B KATZ, THE UNDESERVING POOR: FROM THE WAR ON POVERTY TO THE WAR ON WELFARE 93 (1989).

94 Michael B Katz, The Undeserving Poor: From the War on Poverty to the War on Welfare 99 (1989).

${ }^{95}$ Robert R. Korstad \& JAmes L. Leloudis, To Right These Wrongs: The North CAROLINA Fund AND THE BATTLE TO END POVERTY AND INEQUALITY IN 1960S AMERICA 170 (2010).

96 J. David Greenstone and Paul E. Peterson, Race and Authority in Urban Politics: Community PARTICIPATION AND THE WAR ON POVERTY 4 (1976). 
communities. $^{97}$ In this far more politicized strategic vision of Community Action, participation was not a cure to address the purported apathy and resulting delinquency of the poor. Instead it was a tool to be wielded by community members seeking to address the needs of their communities. As Annelise Orleck describes it in her introduction to a recently published set of grassroots histories of the War on Poverty, Community Action sparked activism in communities across the country.

Previously apolitical poor mothers became swept up by the idea that they could do the heavy lifting in transforming and revitalizing their communities. Paid by Community Action Program funds, poor black women in Memphis scoured their neighborhoods documenting the conditions that led to devastatingly high infant mortality rates. . . . Poor black and white mothers in the Southeast, Puerto Ricans in the Bronx, and Chicanas in the West organized for better health care, housing and education for their children. . . . In Baltimore, Black Power leaders fought for War on Poverty monies to develop community-run housing projects. In Milwaukee, Chicago activists sought funding through the Economic Opportunity Acts migrant worker provisions, not simply to deliver services but also to empower and politicize Tejano farm laborers . . . . In New York's Chinatown, community organizers . . . [sought] federal grants to fund construction of desperately needed affordable housing. ${ }^{98}$

There is virtually no doubt, as Orleck notes, that "politicizing welfare mothers was not part of Johnson's or Shriver's blueprint." "99 But nevertheless in communities across the country, this grassroots, activist vision of participation and community action competed with the service provision and opportunity deprivation theories for control of the program. OEO's internal attempts to define participation mirror these ideological struggles.

\section{Implementing the Mandate Over Time}

Both OEO and Congress acted, between 1964 and 1967, to define the meaning of the participation mandate and to navigate the complicated waters of the threat to local political power embodied in the mandate. The original act, in 1964, contained only the provision described above - that a community action program must be, "developed, conducted, and administered with the maximum feasible participation of residents of the areas and members of the groups served."100 Between 1964 and 1967, when Congress severely narrowed the

\footnotetext{
${ }^{97}$ For a tremendous collection of essays describing the mobilization of poor communities during and as a result of the War on Poverty see generally ANNELISE ORLECK \& LISA GAYLE HARIZRJIAN, EDS., THE WAR ON POVERTY: A NEW GRASSROOTS HISTORY 1964-1980 (2011).

${ }^{98}$ Annelise Orleck, Introduction: The War on Poverty from the Grass Roots Up, THE WAR ON POVERTY: A NEW GrassRoOTS HISTORY 1964-1980 (2011)(ANNELISE ORLECK \& LISA GAYLE HARIZRJIAN, EDS.), 12-13.

${ }^{99}$ Annelise Orleck, Introduction: The War on Poverty from the Grass Roots Up, THE WAR ON POVERTY: A NEW GRASSROOTS HISTORY 1964-1980 (2011)(ANNELISE ORLECK \& LISA GAYLE HARIZRJIAN, EDS.), 12.

${ }^{100}$ Publ. L. No 88-452, 78 Stat. 516. $§ 201$.The struggles over the role of poor people, the federal government, and state and local power structures in fact began before the legislation was passed. In the early months of 1964,
} 
flexibility of the agency to fund diverse and sometimes conflicting organizations in communities, ${ }^{101}$ the agency struggled to define what the participation mandate meant. In shaping that definition, OEO's efforts focused on three distinct areas: first, representation on the governing body of the Community Action agency; second ensuring participation in implementation and finally, and most controversially, devising a role for organizations not under the control of the locally designated Community Action Agencies. It was this final experiment, in which the federal government funded independent community, based mobilizing agencies that Community Action engaged in its most controversial and, from the perspective of those invested in using Community Action to transfer political power into poor communities, most effective endeavor.

\section{Participation in the Community Action Agency Governing Body}

In October 1965 OEO issued a comprehensive guide to Community Action. The one hundred page guide contained detailed information on every aspect of the program. While the agency allowed for significant flexibility in how Community Action Programs would be governed, they clearly sought to assure that poor people would have a substantial role in policy making. The agency mandated that the principal policy-making or governing body of a local CAA include, in addition to representatives from private and public agencies and other constituencies $^{102}$ "[representatives of] residents of the areas and members of the groups to be served." 103 The precise nature of the body, and the extent of that body's power to effect policy, was left to a certain amount of discretion. The administrative mandate, for example,

as Johnson's administration worked to pass the bill, Southern politicians saw in it another means for the federal government to prosecute a civil rights agenda in the South. For the sake of political expedience, Johnson ultimately agreed to the inclusion the Act, of a provision allowing governor's to veto a Community Action program proposal and bar its implementation in the state. Annelise Orleck, Introduction: The War on Poverty from the Grass Roots Up, THE WAR On PoverTy: A NeW GRASSROOTS HISTORY 1964-1980 (2011)(ANNELISE ORLECK \& LISA GAYLE HARIZRJIAN, EDS.), 10.

${ }^{101}$ Much of the controversy surrounding Community Action arose from the funding, by OEO, or organizations who used those resources to oppose the actions of local governments. Over time this led to a substantial backlash against the program. Ultimately, in 1967, Congress stripped the agency of the power to fund oppositional organizations by granting veto power over who OEO funded to state and local government. Specifically, the amendment added Section 210(a) to the act which stipulated that "A community action agency shall be a State or political subdivision of a State (having elected or duly appointed governing officials), or a combination of such political subdivisions, or public or private nonprofit agency or organization which has been designated by a State or such a political subdivision or combination of such subdivisions, which-

"(1) has the power and authority and will perform the functions set forth in Section 212, including the power to enter into contracts with public and private nonprofit agencies and organizations to assist in fulfilling the purposes of this title, and

"(2) is determined to be capable of planning, conducting, administering and evaluating a community action program and is currently designated as a community.

Pub. L. 90-222, 8 Sta. 691 (codified as amended at 42 U.S.C. 2781(1967).

102 These constituencies included "labor, business, religious and minority groups." OFFICE OF ECONOMIC OPPORTUNITY, COMMUNITY ACTION PROGRAM GUIDE (1965) 6, col. 1.

${ }^{103}$ OfFice of ECONOMiC OpPortunity, COMMUnity ACTION PROGRAM Guide (1965) 6, col. 1. 
applied to the, "policy-making or governing body of the community action agency or, where such membership is not feasible, on a policy advisory committee." 104 In a clear attempt to shore the program against use of this concession to lessen the power of representatives, the agency stipulated that,

[t]he functions of a policy advisory committee shall be to assist in review and establishment of program policies, personnel policies and recruitment, and to act as a hearing board for any citizen groups who may want to propose additions to or changes in the community action program. ${ }^{105}$

Clearly, although the agency was not at that point willing to mandate participation in the governing body as the only option, it did seek to ensure that community residents would have a strong means to pressure the policy-making body. Although the original 1965 program guide did not specify a percentage of representation on the governing body, by 1966 Congress would mandate, and OEO would subsequently affirm, that $1 / 3$ of the governing body had to be comprised of representatives of poor communities. ${ }^{106}$

The agency further stipulated that the selection process by which community representatives were to be chosen, "should be designed to encourage the use, whenever feasible, of traditional democratic approaches and techniques such as group forums and discussions, nominations, and balloting." "107 The democracy based rationale for this position was articulated in 1965 by the House of Representatives in a House Report on amendments to the bill.

It is indeed vital that the persons who are the objects of this program be treated 'less as clients or cases and more as partners" (Office of Economic Opportunity, Apr. 30, 1965). The committee is aware that any other mode of operation would be demoralizing to the groups to be served by the act. On the other hand, the idea that the residents of the area and members of the groups served should have sufficient representation on the community action boards, where such boards exist, conforms with a fundamental analogy-that of democracy. ${ }^{108}$

Although administrators faced substantial opposition and continual attempts to avoid the

104 Office of Economic Opportunity, Community Action Program Guide (1965) 17, col. 2 (emphasis added).

105 OfFice of ECONOMIC OPPORTUNITY, COMMUNITY ACTION Program GUIDE (1965) 17, col. 2.

10689 Pub. L. 794, 80 Stat. 1457 (codified as amended at 42 U.S.C 2782) (1966) (requiring defunding of any community action program, "coordinated by a board on which representatives of the poor do not comprise at least one-third of the membership"); OfFICE OF ECONOMIC OPPORTUNITY EXEC. OfF. OF THE PRESIDENT, COMmunity ACtion PRogram Memo No. 57, Revised ReQuirements For REPRESENTATION OF THE POOR ON THE GOVERNING BOARDS OF OVERAL COMMUNITY ACTION AGENCIES (1966) .

${ }^{107}$ OFFICE OF ECONOMIC OPPORTUNITY, COMMUNITY ACTION PROGRAM GUIDE (1965) 6, col. 1.

${ }^{108}$ H. REP. NO. 428, at 9-10 (1965). 
mandate and minimize the impact of representation, ${ }^{109}$ OEO remained committed to ensuring compliance with the board representation mandates and in fact regularly withheld funding based on the failure of CAAs to comply.

\section{Additional Requirements Regarding Participation}

The agency was clear that representation on the governing body was not, in and of itself, sufficient to comply with the statutory participatory mandate. As Sargeant Shriver, the Director of OEO, reaffirmed in a 1966 memo, "[o]ur insistence on participation of "the residents of the areas' has not been limited to, and will not be limited to, membership on CAP governing boards. ..."110 As the agency mandated,

[t]he requirement of resident participation applies to all stages of a community action program, from its inception on. Achievement of meaningful participation shall be a continuing objective of every community action program. ... 111

The agency listed a wide range of means by which CAAs could include participation in "all stages of the program." Among the suggestions were:

use of existing ... and creation of new representative neighborhood organizations for advice on program policy . . . The provision of meaningful opportunities for residents, either as individuals or in groups, to protest or to propose additions to or changes in the ways in which a community action program is being planned or undertaken. . . Employment of residents in CAA work, and a wide range of outreach strategies including surveys, "grassroots involvement committees"; citizen forums, block clubs, newspapers, petitions and referendums. ${ }^{112}$

This emphasis on involving the poor in the work of the agencies of Community Action was clearly quite consonant with Cloward and Ohlin's Opportunity Deprivation theory. Under this theory, involving the poor in the work of these agencies would decrease "alienation." It was, however, in the willingness of OEO to fund organizations led by poor people that Maximum Feasible Participation found its most robust and controversial interpretation.

\section{The Role of Independent Groups in Community Action}

Among the alternatives proposed by the OEO in 1965 to achieve maximum feasible participation was, as noted above, the creation of new and/or support of established

${ }^{109}$ See infra notes __ and accompanying text.

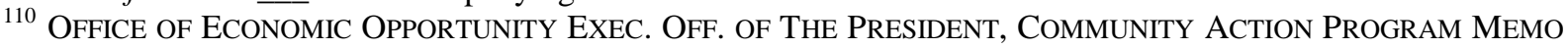
No. 49, MEMORANDUM FROM THE DiRECTOR (1966) 1.

${ }^{111}$ OfFice OF ECONOMIC OPPORTUNITY, COMMUNITY ACTION PROGRAM GUIDE (1965) 16, col. 2.

${ }^{112}$ OfFice of ECONOMic OpPortunity, COMMUNity ACTION Program Guide (1965) 16, col. 1-2. 
community based organizations. In the 1965 Program Guide, OEO made clear that it was particularly important to explore the possibility of creating autonomous groups, "in order to enable them to advise and inform the Community Action Agency and other institutions about the needs, problems and concerns of the poor. Where [such organizations] were absent or without the confidence of the poor, [CAA] staff [could] be made available for the purpose of developing local autonomous associations and organizations."

In the 1966 amendment to the EOA, Congress supported this strategy by explicitly allowing Title II funds to go to "local agencies, which are not now or do not intend to remain delegate agencies of a CAA" ${ }^{\prime 13}$ and set aside at least $5 \%$ of Title II funding for this purpose. In implementing this new requirement, OEO explained that this funding was to be used to support the goals of garnering participation. The agency articulated a funding preference for organizations, "which display an unusually high degree of involvement of poor persons in their initiation and operation."114 Although OEO would institute procedures whereby the relevant CAA would be consulted to ensure non-duplication of services, the local CAA would not have veto power over these funding decisions. ${ }^{115}$

The ability to form and receive funding for autonomous community based organizations that engaged in struggles against local government was a very small part of what OEO actually did. ${ }^{116}$ Despite the minimal actual use of this tool, however, it generated opposition that would ultimately lead to the wresting of control for Community Action out of the hands of communities and firmly into the hands of local and state government. ${ }^{117}$ Before turning to those controversies, however, the following section details the actual extent and impact of participation of the poor in Community Action overall.

\section{Participation in Community Action: Extent and Impact}

Despite the apparent dedication by OEO to realizing participation, and extraordinary political rhetoric about the threat to the social order posed by Community Action at the time, 118 in reality, in the vast majority of locations, the presence of representatives in poor communities neither fundamentally altered the service provision focus of Community Action nor provided a meaningful platform for community based groups to wield significant power in fights against entrenched local power.

\footnotetext{
11389 Pub. L. 794, 80 Stat. 14579 (codified as amended at 42 U.S.C 2782) (1966).

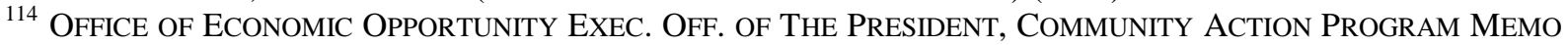
No. 9-A (1967) 4.Memo 9-A at 4.

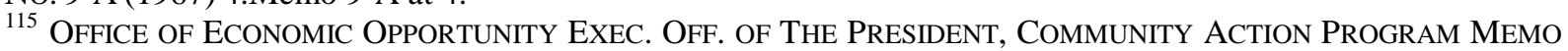
No. 9-A (1967) at 5.

${ }^{116}$ See infra notes ___ and accompanying text.

117 See infra notes ___ and accompanying text. See also PETER MARRIS \& MARTIN REIN, DILEMMAS OF SOCIAL REFORM: POVERTY AND COMMUNITY ACTION IN THE UNITED STATES 259 (1973).

${ }^{118}$ See infra notes ___ and accompanying text.
} 


\section{A. Participation Overall: The View From the Period}

The extent and effectiveness of participation by poor communities in Community Action was the subject of extensive study in the years shortly following its demise. ${ }^{119}$ For example 1973, Peter Marris and Martin Rein published a widely cited study of Community Action entitled Dilemmas of Social Reform: Poverty and Community Action in the United States. ${ }^{120}$ Marris and Rein were originally hired by two principle agencies devoted to the ideas of Community Action, the Ford Foundation and the President's Committee on Juvenile Delinquency, to study the effectiveness of the program. Their study focuses in large part of the extent and effectiveness of participation by the poor. As they describe a primary conclusion of their study in their Epilogue,

Despite OEO's insistence on the representation of the poor, they were scarcely involved in the initiation of community action agencies, and though they were brought onto their controlling boards in time, the programmes continued to reflect the interests of the original promoters - the mayor, the voluntary agencies, the school system, welfare departments, universities. . . . Nor did the essential pattern change as time went by. The community action agencies ran barely a fifth of the programmes themselves, contracting out the rest mostly to the school system and the voluntary welfare agencies. $^{121}$

Another study published in 1972 by David Austin affirms Marris and Rein's basic conclusions. Although the poor did appear on CAA boards, in the vast majority of circumstances their presence had very little substantive effect either on the content of the program or the political power balance in their community. Austin describes the implementation of Community Action in twenty cities from March 1967 to July $1968^{122}$ and focuses on the extent and effectiveness of participation in those locations. These studies reveal that, despite compliance with the one-third board membership mandate, the effect of this participation was small. In all 20 cities, the CAA complied with the board membership

\footnotetext{
${ }^{119}$ In addition to the studies discussed in this Section, see e.g. J. DAVID GREENSTONE AND PAUL E. PETERSON, RACE AND Authority in URban Politics: COMMUNity PARTICIPATION AND THE WAR ON POVERTy (1976);

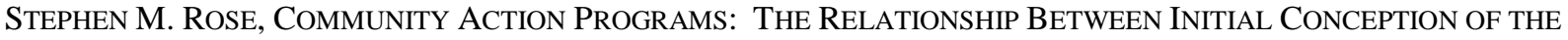
POVERTY Problem, DERIVED INTERVENTION STRATEGY AND PROGRAM IMPLEMENTATION 97 (1970).

${ }^{120}$ The study was actually originally printed in 1967 and was then updated and reissued in 1973.

${ }^{121}$ PETER MARris \& MARTIN REIN, DILEMMAS OF SOCIAL REFORM: POVERTY AND COMMUNITY ACTION IN THE UNITED STATES 258 (1973). In further support of this point Marris and Rein quote another study by S.M. Rose on the extent and effectiveness of participation of Community Action in twenty cities. As Rose describes it, "“. . . there were no poor people, no residents of poverty neighborhood, no members of the groups to be served involved in th initiation of the local community action agencies or in the initial programme development in the twenty cities in the sample."'(Citing S.M. Rose, "Community Action Programs: The Relationship between initial conception of the Poverty Program, Derived Intervention Strategy and Program Implementation'. Brandeis Thesis, 1970 (Ann Arbor, University Microfilsm, 1970).

122 David M. Austin, Resident Participation: Political Mobilization or Organizational Co-Optation?, 32 PuBLIC ADMIN. REV. 409-10 (1972).
} 
mandate and, community representatives across jurisdictions attended meetings at rates similar to their non-community representative colleagues. ${ }^{123}$ Despite this facial compliance and participation, community members had, in general, very limited impact. Austin finds that community members, or what he calls "target-area representatives" had, "little or no part in the initial organization of the CAAs and in the decisions made about organizational structure. ..."124 Representatives also had, "very little impact on the major program strategies and mix of programs carried out by the local CAA . . ." 125

In addition, Austin discusses the quality or nature of the participation. He breaks participation down into two major categories: organizational and political participation. Organizational participation is defined as the utilization, by local communities, of the established governmental structure within CAA. In contrast political participation arose in circumstances in which, "[t]he CAA neighborhood organization community-mobilization component was used to strengthen the political base of target-area resident in the pluralistic power conflicts of the larger community." 126 Within organizational participation, then, are three further categories that differ by the extent to which communities effectively utilized their position on the CAA board. ${ }^{127}$ Those three categories are limited, active and adversary organizational participation. As the terms suggest, limited participation is characterized by low level participation of target-area board members in the CAA board, little or no neighborhood organizing component, focus on short term neighborhood improvement projects, and limited involvement in reviewing CAA proposals and no involvement in public controversies. ${ }^{128}$ Active participation is defined as a relatively higher level of participation by target-area board members but a lack of target-area board members acting as voting bloc in CAA board decisions and, a failure, when the target-area representatives did advocate together, to prevail in those board actions. Representatives in active participation jurisdictions did have a formal advisory role in program planning for their area and occasionally became

${ }^{123}$ David M. Austin, Resident Participation: Political Mobilization or Organizational Co-Optation?, 32 PUBLIC ADMIN. REV. 411 (1972).

${ }^{124}$ David M. Austin, Resident Participation: Political Mobilization or Organizational Co-Optation?, 32 PUBLIC ADMIN. REV. 412 (1972).

125 David M. Austin, Resident Participation: Political Mobilization or Organizational Co-Optation?, 32 PuBLIC ADMIN. REV. 412-13 (1972). Marris and Rein cite their own as well as other studies and come to similar conclusions. As they describe it, "' ... [T] [Tere were no poor people, no residents of poverty neighborhoods, no members of the groups to be served involved in the initiation of the local community action agencies or in their initial program development ..” PETER MARRIS \& MARTIN REIN, DILEMMAS OF SOCIAL REFORM: POVERTY AND COMmunity ACTION IN THE UNITED STATES 258 (1973)(Quoting S.M. Rose, Community Action Programs: The Relationship between initial conception of the Poverty Program, Derived Intervention Strategy and Program Implementation. Brandeis Thesis, 1970 (Ann Arbor, University Microfilsm, 1970) 181-82).

${ }^{126}$ David M. Austin, Resident Participation: Political Mobilization or Organizational Co-Optation?, 32 PUBLIC ADMIN. REV. 414 (1972).

${ }^{127}$ David M. Austin, Resident Participation: Political Mobilization or Organizational Co-Optation?, 32 PUBLIC ADMIN. REV. 413-16 (1972).

${ }^{128}$ David M. Austin, Resident Participation: Political Mobilization or Organizational Co-Optation?, 32 PuBLIC ADMIN. REV. 414 (1972). 
involved in controversies on issues external to the CAA. ${ }^{129}$ Finally adversary participation is defined as high level of participation of target-area board members in board action; consistent operation as a voting-bloc by target-area representatives; and an ability to win on key issues against the opposition of CAA staff and board leadership. ${ }^{130}$ Of the seventeen jurisdictions described by Austin as characterized by some degree of "organizational representation" only four were characterized as having "adversary participation.",

Three additional jurisdictions were characterized by Austin as having political adversary participation. Those jurisdictions were characterized by a high degree of organizing, mobilization and advocacy on issues impacting poor communities. By and large Austin describes community mobilization in those jurisdictions as successful both in terms of the outcomes within the governing body and in addition successful at the development of political leadership within poor communities. ${ }^{132}$ So to summarize perhaps too reductively, in only seven of the twenty jurisdictions did the presence of Community Action appear to correlate with an ability to impact the agenda of the governing body and in only three of those seven did it correlate with an additional transfer of political power in poor communities.

In addition, the presence of Community Action Agencies did not actually result in a move away from the culture of poverty thesis or the dominance of a service / income maintenance model provided by previously established social service providers. ${ }^{133}$ The vast majority of the programs of War on Poverty subscribed to a theory that poverty could be addressed primarily through services and aid. By and large, Community Action Agencies followed this model. According to some studies in the late 1960s and 1970s, 90\% of Community Action programs focused on individual as opposed to institutional change; $85 \%$ were service oriented; $10 \%$ were directed toward income maintenance and less than 5\% were focused on institutional change. ${ }^{134}$ In addition, the vast majority of programs were ultimately administered not by new community controlled agencies but by established providers, primary "the school system[s] and the voluntary welfare agencies." ${ }^{135}$

\footnotetext{
${ }^{129}$ David M. Austin, Resident Participation: Political Mobilization or Organizational Co-Optation?, 32 PUBLIC ADMIN. REV. 414-15 (1972).

${ }^{130}$ David M. Austin, Resident Participation: Political Mobilization or Organizational Co-Optation?, 32 PubliC ADMIN. REV. 415 (1972).

${ }^{131}$ David M. Austin, Resident Participation: Political Mobilization or Organizational Co-Optation?, 32 PuBLIC ADMIN. REV. 415 (1972). Austin categories eight of the jurisdictions as having "limited participation" and the remaining five as having "active participation." Id.

${ }^{132}$ David M. Austin, Resident Participation: Political Mobilization or Organizational Co-Optation?, 32 PUbLIC ADMIN. REV. 416-17 (1972).

${ }^{133}$ For a discussion of these models see supra notes ___ and accompanying text.

${ }^{134}$ Peter Marris \& Martin Rein, Dilemmas OF Social Reform: Poverty and COMMUNITY Action IN the United States 258 (1973)(citing Stephen M. Rose, The Betrayal of the PoOR: THE Transformation of Community action (1972); Kenneth B. Clarke \& Jeanette Hopkins, A Relevant War Againt POVERTY (1969).

${ }^{135}$ Peter Marris \& Martin Rein, Dilemmas of Social Reform: Poverty and Community Action in the UNITED STATES 258 (1973).
} 
Despite what appears, from both Austin and Marris and Rein's data to be the relatively small overall impact of community representatives on both local power structures and program design and the ultimate maintenance of service driven model largely within the control of preexisting established agencies, there is no question that Community Action generated substantial opposition and was ultimately engulfed in a political firestorm. Understanding this dichotomy between the actual impact of poor communities on the program and the purpoted threat posed by participation requires looking squarely at how Community Action and the War on Poverty were intertwined with race politics at the time.

\section{Civil Rights Activism, Race Politics and Backlash}

Up to this point, this Section has described Community Action largely outside the context of race. However, without understanding the racial context, one cannot understand what actually occurred. The Economic Opportunity Act was passed in 1964, the same year as the Civil Rights Act. The year leading up to the passage of both these pieces of legislation saw among other watershed events, Freedom Summer, King's Letter from a Birmingham City Jail, and the March on Washington. In the same period, in cities like Newark, Chicago, Los Angeles, and Philadelphia, communities reached a boiling point over, "poverty and racism, inadequate schools, and lack of jobs," resulting in widespread destruction of low income communities. ${ }^{136}$ Community Action was implemented, in the South, in the very same communities that had been waging pitched battles over school desegregation and in the midst of profound opposition to federal intervention in any form.

Although examples abound, ${ }^{137}$ Kent B. German's description of the ultimate causes of the failure of the War on Poverty in the Mississippi Delta is representative. As he describes it,

President Johnson's beloved initiative was not equipped to alter the social, cultural and economic conditions of a region whose leadership tended to prefer preserving white supremacy over economic innovation, quality public education, and investment in human capital. For some of the region's most powerful leaders, the War on Poverty and its supporters were the enemies, and if they could not be denied, they needed to be curtailed and controlled. $^{138}$

\footnotetext{
${ }^{136}$ Annelise Orleck, Introduction: The War on Poverty from the Grassroots Up, THE WAR ON POVERTY: A NEW GRASSROOTS HISTORY 1964-1980 (2011)(ANNELISE ORLECK \& LiSA GAYLE HARIZRIJAN, EDS.) 13-14.

137 For examples of the way in which Community Action challenged entrenched white power and the extraordinary backlash against that challenge, see e.g. See Kent B. German, Poverty War in the Louisiana Delta: White Resistance, Black Power and the Poorest Place in America, Greata de Jong, Plantation Politics: The Tufts-Delta Health Center and Intraracial Class Conflict in Mississippi, 1965-1972, and Amy Jordan, Fighting for the Child Development Group of Mississippi: Poor People, Local Politics, and the Complicated Legacy of Head Start, all in THE WAR ON POVERTY: A GRASSROOTS History 231-307 (Annelise Orleck \& Lisa Gayle Hazirjian Eds.) (2011).

${ }^{138}$ See Kent B. German, Poverty War in the Louisiana Delta: White Resistance, Black Power and the Poorest
} 
The pitched battles waged over the implementation of Head Start in the South provide an important example. Head Start was one of several OEO national demonstration projects that would come to play a prominent role in War on Poverty. However, in the Louisiana Delta, "the federal effort to address long-standing poverty became part of the battle over ending the approximately eight-year-old system of racial segregation known as Jim Crow.",139 Predictably, "[b]ecause the OEO required the racial integration of Head Start programs at a time when almost all Louisiana school boards were still defying federal desegregation rulings, white segregationists came to see preschool classes as a despised symbol of federal power and black advancement." ${ }^{\prime 40}$ In communities across the South the battle over Head Start was at the forefront of the fight against the War on Poverty.

Although the conclusions of Marris and Rein and Austin describe the overall impact of the program, it is also certainly true that Community Action did in some locations, channel dollars into organizations largely controlled by poor communities. Although the scale was small in comparison to the overall program, the implications for these instances were profoundly threatening to those who sought to maintain racial capitalism. And the backlash against Community Action wielded many of the tools that had been used successfully against Civil Rights organizations and was, in many senses, swift and effective. As Annelise Orleck has noted,

[d]uring the summer of 1964 and in the turbulent summers that followed, urban machine Democrats and southern Dixiecrats who had loyally delivered votes to Lyndon Johnson complained bitterly about federal dollars being channeled to community activists believed to be fomenting riots of the government's dime, lighting matches in cities that were highly flammable. ${ }^{141}$

In many communities, community controlled organizations funded by the federal program were attacked in ways that were remarkably similar to attacks against civil rights organizations. Klan violence abounded. Community Action leaders were accused of having communist sympathies $^{142}$ and organizations were accused of misusing federal funds and

Place in America, in The WAR ON POVERTy: A Grassroots History 232 (Annelise Orleck \& Lisa Gayle Hazirjian Eds.) 232 (2011).

${ }^{139}$ See Kent B. German, Poverty War in the Louisiana Delta: White Resistance, Black Power and the Poorest Place in America, in THE WAR ON POVERTY: A GRASSROOTS History 232 (Annelise Orleck \& Lisa Gayle Hazirjian Eds.) 233 (2011).

${ }^{140}$ See Kent B. German, Poverty War in the Louisiana Delta: White Resistance, Black Power and the Poorest Place in America, in The War on Poverty: A Grassroots History 232 (Annelise Orleck \& Lisa Gayle Hazirjian Eds.) 233 (2011).

${ }^{141}$ Annelise Orleck, Introduction: The War on Poverty from the Grassroots Up, THE WAR ON POVERTY: A NEW GRASSROOTS HISTORY 1964-1980 (2011)(ANNELISE ORLECK \& LISA GAYLE HARIZRIJAN, EDS.) 14.

${ }^{142}$ For an in depth example of an attacks on War on Poverty funded activist organizations and funders being accused of having communist party ties, see ROBERT R. KORSTAD \& JAMES L. LELOUDIS, TO RIGHT THESE 
engaging in fraud. ${ }^{143}$ Ultimately, although many of the investigations yielded little actual evidence of wrongdoing, in many cases, by that time the damage was done. ${ }^{144}$ Johnson, who never fully endorsed more radical interpretations of Community Action, quickly bowed to this pressure. $^{145}$

Between 1963 and 1970, local and state officials seeking to maintain political power and racial capitalism, succeeded in eliminating the ability of OEO to destabilize local power through community action. The struggles over local control began even before passage of the legislation, when Johnson agreed to a governor veto power in the original act. Between 1964 and 1968, the agency increasingly exercised its ability to bypass local CAAs and fund local community organizations directly. However, as some local organizations took hold of this possibility and used funds to support mobilization and political protest campaigns, ${ }^{146}$ both Congress and to OEO balked. In 1966 Congress amended the act,

to preclude the use of program funds, the provision of services, or the employment or assignment of personnel in a matter supporting, or resulting in an identification of such programs with, any partisan political activity or any activity designed to further the election or defeat of any candidate for public office. ${ }^{147}$

Similarly, in March 1966 OEO, issued a memo declaring that,

"[m]embership in subversive organizations or lack of sympathy with the objectives of the Economic Opportunity Act of 1964 . . . are inconsistent with membership on the governing bodies and policy advisory committees of community action agencies or single-purpose agencies finances under Title II-A of the Act. ${ }^{148}$

By 1967, with the passage of the Green and Quie Amendments (which took effect in 1968) local officials were authorized to choose the "representatives" of "residents of affected

Wrongs: THE NoRTh CAROLINA Fund AND THE BATTLE TO END POVERTY AND INEQUALITY IN 1960S AMERICA 328-33 (2010).

${ }^{143}$ See Annelise Orleck, Introduction: The War on Poverty From the Grassroots Up, in THE WAR ON POVERTY: A GRASSROOTS HISTORY (Annelise Orleck \& Lisa Gayle Hazirjian Eds.) 16 (2011)

${ }^{144}$ See Annelise Orleck, Conclusion The War on the War on Poverty and American Politics Since the 1960s, in THE WAR ON POVERTY: A GRASSROOTS HISTORY 455 (2011)(discussing the widespread use of allegations of fraud against federal poverty programs).

${ }^{145}$ For an in depth look at Johnson's view of Community Action See Guian A. McKee, "'This Government is With Us': Lyndon Johnson and the Grassroots War On Poverty in THE WAR ON POVERTY: A NEW GraSSROOTS HISTORY 1964-1980 (Annelise Orleck \& Lisa Hazirjian Eds.)

${ }^{146}$ See infra notes _ and accompanying text for an example of these campaigns.

14789 Pub. L. 794, 80 Stat. 1457 (codified as amended at 42 U.S.C 2782) (1966).

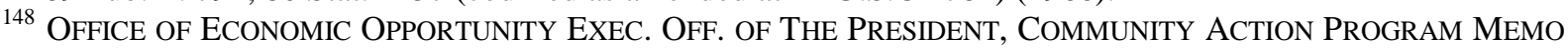
No. 24 (1967). In 1966 in at least one instance OEO also ruled against the use of federal funds to support protest activities. Christina Greene, Our Separate Ways: Women and The Black Freedom Movement in DURHAM, NORTH CAROLINA 127 (2005). 
communities." In a devastating blow to organizations using funds to support often controversial and threatening grassroots organizing campaigns, the amendment gave local officials the power to designate which community organizations were eligible for federal funds. The final nail in the coffin came in 1970, when President Nixon, and his OEO Chief Donald Rumsfeld, gave states official control of the anti poverty programs. ${ }^{149}$ Community Action would continue in a less controversial form for years to come, but it's days as a tool to support mobilization were over. ${ }^{150}$

Despite this discouraging history, many historians agree that, although Community Action in its dominant mode was not characterized by participation that either had a significant impact on program content or seriously threatened the political power base in communities, there were some exceptions. First, the participatory mandate did in some circumstances provided a catalytic structure around which some communities could organize and through which they could make change. But this change did not generally occur, as perhaps program administrators hoped, within the formal governing structures of Community Action. Community Action agencies largely continued to deliver services as they had before, and, in large part due to political opposition to the program, increasingly Community Action narrowed its purpose - away from community-based experimentation and toward the implementation of nationally administered and conceptualized programs like Head Start and Job Corps.

As Marris and Rein noted in 1973, however, while Community Action failed in many respects, it:

... did provide a structure through which black leaders could emerge and . . . argue with the political establishment. It gave them jobs, access to professional advice, a platform; . . . Much of this might have happened anyway, but Community Action facilitated it, and here and there, at least, helped to redress the balance of power in American cities. ${ }^{151}$

In this sense, Community Action did in fact create significant opportunities for the development of robust organizations and individuals in poor communities who would go onto wield increased political power in those communities. It is to those instances, where

\footnotetext{
149 Annelise Orleck, Introduction: The War on Poverty from the Grassroots Up, THE WAR ON POVERTY: A NEW GRASSROOTS HISTORY 1964-1980 (2011)(ANNELISE ORLECK \& LISA GAYLE HARIZRIJAN, EDS.) 18.

${ }^{150}$ While the use of Community Action as a tool for mobilization was certainly over, in the late $20^{\text {th }}$ Century in some sense it would be replaced by the Community Economic Development Movement. For a detailed look at that form of market activism, see WiLliam H. SimON, THE COMMUNITY ECONOMIC DEVELOPMENT MOVEMENT: LAW, BUSINESS AND THE NEW SOCIAL POLICY (2001).

${ }^{151}$ PETER MARris \& MARTIN REIN, DilemMAs OF SOCIAL REFORM: POVERTY AND COMMUNITY ACTION IN THE United StATES 269 (1973). See also Austin at 418 (The provisions of the law did establish a principle which could be used by local groups that were already mobilized to support their demands for inclusion of low-income citizens in decision making.).
} 
participation was in fact quite robust and effective in this sense, that the following section turns.

\section{Robust Participation At the Margins: North Carolina and Beyond}

At this point it should be clear that, despite what appeared to be some level of commitment by federal administrators to ensure significant participation by poor communities in Community Action, effective and meaningful participation largely did not result in representatives of the poor having a strong impact on program content. Participation, although nominally present in the form of representation on Community Action boards generally did not result in giving poor people any significant power to effect program structure or policy. ${ }^{152}$ Thus perhaps for those who would seek to glean from this history examples of how to implement effective, collaborative participatory governance, the history offers only lessons either in what not to do or in the difficulties of the endeavor, particularly in areas charged by a history of subordination. But from the perspective of those, either inside or outside the governance endeavor, interested in shaping and wielding participatory opportunities when they arise, on behalf of the self-articulated interests of poor communities, the history offers something slightly different and more promising. At moments, in the interactions between a statutory and regulatory participation mandate, administrators who were flexible as to means but committed to, or at least willing to be pulled toward, robust forms of participation and effective advocacy by poor communities, participation in fact worked tremendously well. It is to those instances and interactions, as they played out for a time in Durham, North Carolina, that this section turns.

\section{A. Robust Participation Defined}

Before proceeding to describe what happened in Durham, a definition of what this article terms "robust participation" is required. For these purposes, participation was "robust," as a result of the participatory opportunity if two things happened. First, as a result of the participatory opportunity, representatives of poor communities were able help create policies and programs that they believed to be in their communities' interest. Borrowing a term from political scientists and evaluators of Community Action at the time, this article describes this ability effectively to wield power on behalf of the represented community as robust "substantive participation." ${ }^{153}$ Second, the article seeks

\footnotetext{
${ }^{152}$ This is not to say that there were not significant shifts in American policy as a result of the War on Poverty and Community Action. That is clearly not the case. See infra... It, is however, the case that Community Action failed in its goal to use the mechanisms of community action to design, with the poor, a better way to conduct American poverty policy.

${ }^{153}$ For the first part of this definition, the term "substantive participation" 153 offered by J. David Greenstone and Paul E. Peterson in their 1973 study of Community Action provides some help. In that study Greenstone and Peterson evaluate the extent, nature and effectiveness of participation in Community Action Programs during the War on Poverty in five northern cities. As part of that evaluation, Greenstone and Peterson offer descriptions of forms and characteristics of representation. J. DAVID GREENSTONE AND PAUL E. PETERSON, RACE AND
} 
to describe circumstances where, as a result of the participatory opportunity, some measure of political power seemed to transfer into the hands of community members. ${ }^{154}$ Thus, below the article describes participation as "robust" if the participatory opportunity resulted in two things that one can assume are reasonable goals for individuals seeking to utilize participatory mechanisms on behalf of poor communities. First, was there robust substantive participation and second, did political power transfer occur?

\section{B. Robust Participation In Context}

While this Section focuses on specific structures and interventions that seemed, in North Carolina and beyond, to correlate with robust participation, it is important to acknowledge that the robustness of participation probably had much more to do with the particularities of local socio-political contexts than with the role of law, governance and strategic advocacy. There is no doubt that a wide range of factors on the ground mattered tremendously. Central among them were the relative strength of Civil Rights and Labor Rights organizing in the location, the relative cohesiveness and strength of local governments that opposed robust participation and the specific characteristics of local government. For example, Korstad and Leloudis, who offer a rich history of the War on Poverty in North Carolina, identify prior history of civil rights and labor rights organizing as key factors that led to robust participation in North Carolina. Greenstone and Peterson also offer a detailed and nuanced study about how the

Authority In Urban Politics: COMMunity PARTicipation AND the WAR ON POVERTy 166-99 (1976). Greenstone and Peterson attribute their representation definitions to HANNAH PITKIN, THE CONCEPT OF REPRESEntATION (1967), See GREENSTONE AND PETERSON at 166 n. 2. Nevertheless for ease of argument, this article will refer to the definition as Greenstone and Peterson's. Greenstone and Peterson sought to measure, among other things, how much power representatives wielded and the extent to which the representative's "orientation agree[s] with his constituent's interests" or to phrase it another way, they asked whether the representative actually wielded whatever power she had on behalf of the interests of her constituents as a whole. J. David Greenstone And Paul E. Peterson, RaCe And Authority in Urban Politics: COMMunity PARTICIPATION AND THE WAR ON POVERTY 167-68 (1976). If the representative both wielded significant power, i.e. that person had the requisite political capital to ensure that the decisions of the body would be decided in their favor and if that representative pursued "universalistic" (as opposed to patronage focused) gains, Greenstone and Peterson defined the jurisdiction as one in which there was a high degree of substantive representation.

154 While the details of the studies conducted in the late 1960s and 1970s are beyond the scope of this article, researchers at the time did seek to measure this kind of political power transfer. For example, Austin analyzes, among other things, the quality and nature of participation of community representatives, or what he calls "target-area" representatives in twenty cities. As noted above, one analytic category he offers is "political adversary participation." Austin places a city's Community Action Agency in that category if "the operational definition of participation within the CAA [emphasized] its political function . . . [meaning that]. . . [t]he CAA neighborhood organizing-community mobilization component was used to strengthen the political base of targetarea residents in the pluralistic power conflicts of the larger community." In focusing on the extent to which the participatory governance mechanism led to robust substantive representation and political power transfer this article draws in addition from the rich political science literature on participatory democracy. For additional sources on current endeavors in participatory democracy see e.g. Archon Fung and Erik Olin Wright, Thinking About Empowered Participatory Governance, DEEPENING DEMOCRACY: INSTITUTIONAL INNOVATIONS IN EMPOWERED PARTICIPATORY GOVERNANCE 4 (Archon Fung \& Erik Olin Wright eds.,( 2003)). 
presence of "machine" versus "reform" structures in city government strongly impacted the quality and nature of community participation. ${ }^{155}$ In addition it is certainly true that the conditions described below did nothing more than create a possibility for robust participation. The existence of these conditions in no way predicts that robust participation will occur. They are offered simply to suggest that their presence seemed to make it more likely that this endeavor would be successful. To this extent looking at this history for conditions that were, at the time, successfully wielded by sympathetic administrators and dedicated activists to render substantive the participatory mandate provides insight into those who might invest in a similar endeavor today.

\section{Robust Participation At the Margins: Durham, North Carolina}

Across the nation, despite extraordinary pressure against them, communities were pushing the margins of participation. Throughout the country, in places like Baltimore, Houston, Milwaukee, Memphis, New York, and Appalachia, ${ }^{156}$ community members seized the mechanisms of the War on Poverty to further their own rights and social welfare agendas. It is certainly true that much of this mobilization might have happened without Community Action, ${ }^{157}$ but the right to participation and in particular the availability of funding for independent organizations was, in many jurisdictions, a catalyst for both leadership development in poor communities and an opportunity to create programs that, in the view of community controlled organizations, were responsive to their needs.

In 2005 Christina Greene published Our Separate Ways: Women and the Black Freedom Movement in Durham, North Carolina, and in 2010 Robert Korstad and James Leloudis

155 J. David Greenstone and Paul E. Peterson, RaCe And Authority in Urban Politics: Community PARTICIPATION AND THE WAR ON POVERTY (1976).

${ }^{156}$ Rhonda Y. Williams, "To Challenge the Status Quo By Any Means": Community Action and Representation Politics in 1960s Baltimore, THE WAR ON POVERTY: A NEW GRASSROOTS HISTORY 1964-1980 (2011)(ANNELISE ORLECK \& LISA GAYLE HARIZRIJAN, EDS.) 63-86; Wesley G. Phelps, Ideological Diversity and the Implementation of the War on Poverty in Houston, THE WAR ON POVERTY: A NEW GRASSROOTS HISTORY 1964-1980 (2011)(ANNELISE ORLECK \& LiSA GAYlE HARIZRIJAN, EdS.) 87-109; Marc S. Rodriguez, Defining the Space of Participation in a Northern City: Tejanos and the War on Poverty in Milwaukee, THE WAR ON POVERTy: A NEW GrassRoOTS History 1964-1980 (2011)(ANNELISE ORLECK \& LiSA GAYLE HARIZRIJAN, EDS.) 110-132; Laurie B. Green Saving Babies in Memphis: he politics of Race, Health and Hunger during the War on Poverty, THE WAR ON POVERTY: A NEW GRASSROOTS HISTORY 1964-1980 (2011)(ANNELISE ORLECK \& Lisa Gayle HarizRIJAn, EdS.) 133-158; Adina Back, "Parent Power": Evalina Lopez Antonetty, the United Bronx Parents, and the War on Poverty, THE WAR ON POVERTY: A NeW GRASSROOTS HistORY 1964-1980 (2011)(ANNELISE ORLECK \& LiSA GAYLE HARIZRIJAN, EDS.) 184-208; Thomas Keffmeyer, Looking Back to the City in the Hills: The Councils of the Southern Mountains and a Longer View of the War on Poverty in the Appalachian South, THE WAR ON POVERTY: A NEW GRASSROOTS History 1964-1980 (2011)(ANNELISE ORLECK \& LISA GAYLE HARIZRIJAN, EDS.) 359-386.

${ }^{157}$ PETER MARris \& MARTIN REIN, DILEMMAS OF SOCIAL REFORM: POVERTY AND COMMUNITY ACTION IN THE UNITED STATES 269 (1973). 
published To Right These Wrongs: The North Carolina Fund and the Battle to End Poverty and Inequality in 1960s America. Korstad and Leloudis' retelling focuses in large part on the interaction between administrators who sought to realize maximum feasible participation and the poor communities that attempted to use Community Action to serve their own ends. Greene's book centers the stories of often poor, primarily black women and the organizations they founded, ran and influenced in Durham during the period. Together the texts tell a striking story of the relationships between law, participatory mandates, and community activism. They therefore provide rich information with which to begin to look at how, at moments, communities, funders and administrators seized the mechanisms of Community Action to realize both robust substantive participation and political power transfer. What follows in this section is a brief retelling of some of the key moments in these narratives.

\section{Background History}

In 1962, then Governor of North Carolina Terry Sanford was nearing the end of what would be his last term in office and had lost a tremendous amount of his political power base. His failed attempts first to avoid the issue of race and then, when the issue became unavoidable, to stake out a position that was relatively moderate among white political power brokers in North Carolina had served only to undermine his own political power. Sanford was dismissed by Civil Rights Activists who understood that, in the early 1960s, only large scale protest would succeed in the shaming necessary to bring about change. ${ }^{158}$ And he and those promoted by him were vilified by white supremacists as, "captive pawns in the hands of Bobby Kennedy and Martin Luther King" and as part of a, "small but noisy clique of professional Liberals at Chapel Hill who are a red and festering sore upon the body of a great university.",159

At that moment, Terry Sanford, who by all rights should have lived out his term quietly as a lame duck, instead sought to create new governing ground outside the traditional fora, governing ground that would ultimately take hold of Community Action programs in North Carolina. ${ }^{160}$ Sanford had laid the ground for this work earlier that year in meetings with the Ford Foundation. At the time that Sanford approached the foundation, Paul Yliskar, the head of the Public Affairs division of the foundation was seeking opportunities to expand the Gray Areas work into the South but was cautious because of the determination of white supremacists to defend the status quo. ${ }^{161}$ Sanford, working in conjunction with George Esser at the University of North Carolina's Institute of Government, proposed to Ford the creation

\footnotetext{
${ }^{158}$ Robert R. KORSTAD \& JAMES L. LELOUdis, To Right THESE Wrongs: THE North CAROLINA Fund AND THE BATTLE TO END POVERTY AND INEQUALITY IN 1960S AMERICA 72 (2010).

${ }^{159}$ RoBert R. KORSTAD \& JAMES L. LELOUdis, To Right THESE Wrongs: THE NoRTh CAROLINA Fund AND THE BATTLE TO END POVERTY AND INEQUALITY IN 1960S AMERICA 78 (2010).

${ }^{160}$ RoBert R. KORSTAD \& JAMES L. LELOUdis, To Right THESE Wrongs: THE North CAROLINA Fund AND THE BATTLE TO END POVERTY AND INEQUALITY IN 1960S AMERICA79 (2010).

${ }^{161}$ Robert R. Korstad \& JAmes L. Leloudis, To Right These Wrongs: The North CAROLinA Fund And THE BATTLE TO END POVERTY AND INEQUALITY IN 1960S AMERICA 64 (2010).
} 
of the North Carolina Fund, a "pilot project" to

operate as a 'special non-governmental corporation' responsible for 'launch[ing] a Statewide program against poverty and educational deficiencies.' It's charge was to, 'find new and better ways to improve education, economic opportunities, living environment, and general welfare of the people.' 162

Crucially, through the North Carolina Fund, Sanford and his colleagues ". . . created, outside of electoral politics a competing source of legitimacy, influence and financial leverage." ${ }^{63}$ This space was soon to be reproduced, across the nation, through funding under the Community Action program. ${ }^{164}$

The North Carolina Fund opened its doors in September of 1963. It was characterized grandly, as "'the first massive statewide effort in our country to find ways to break the cycle of poverty and dependency.",165 The Fund would focus its efforts on experimentation and would serve as an "intermediary organization" managing and regranting foundation and ultimately federal dollars as "social venture capital that was to be invested in proposals that percolated up from communities.", 166

In the Fund's first call for proposals it articulated several basic ideas that would drive its work. Communities were to submit Community Action Plans ("CAPs") to the Fund. Proposals were to be experimental, focusing on innovation rather than augmentation of existing programs; projects should "represent broad community involvement that included members of the 'target group' - the poor themselves. Finally, the proposals were to demonstrate a commitment to coordination among local agencies. ${ }^{167}$ These commitments were, of course, mirrored a year later in the federal Economic Opportunity Act Maximum Feasible Participation mandate. ${ }^{168}$

As the fund began its work it encountered and attempted to answer two fundamental and tremendously difficult questions that were at the heart of Community Action. How was it to accomplish its objectives in the face of dominant white local power structures that were

\footnotetext{
${ }^{162}$ Robert R. Korstad \& JAmes L. Leloudis, To Right These Wrongs: The North CAROLINA Fund AND THE BATTLE TO END POVERTY AND INEQUALITY IN 1960S AMERICA 82 (2010).

${ }^{163}$ RoBert R. KORSTAD \& JAMES L. LELOUdis, To Right THESE Wrongs: THE North CAROLINA Fund AND THE BATTLE TO END POVERTY AND INEQUALITY IN 1960S AMERICA 83 (2010).

${ }_{165}^{164}$ See infra notes __ and accompanying text

${ }^{165}$ Robert R. Korstad \& James L. Leloudis, To Right These Wrongs: The North CARolina Fund And THE BATTLE TO END POVERTY AND INEQUALITY IN 1960S AMERICA 88 (2010).

${ }^{166}$ RoBert R. KORSTAD \& JAMES L. LELOUdis, To Right THESE Wrongs: THE NORTH CAROLINA Fund AND THE BATTLE TO END POVERTY AND INEQUALITY IN 1960S AMERICA 87 (2010).

${ }^{167}$ RoBert R. KORSTAD \& JAMES L. LELOUdis, To Right THESE Wrongs: The North CAROLINA Fund AND THE BATTLE TO END POVERTY AND INEQUALITY IN 1960S AMERICA 91 (2010).

${ }^{168}$ See infra notes ___ and accompanying text.
} 
determined to preserve segregation and racial capitalism? And, relatedly, what precisely did they mean by community participation. ${ }^{169}$

\section{Durham, North Carolina}

Durham North Carolina was, by every account, an outlier in terms of participation. Austin identified Community Action in Durham as one of only three cities out of twenty that implemented "political adversary participation," 170 the designation for locations, in Austin's analysis, that exhibited what is here described as both robust substantive participation and political power transfer. This finding is in large measure born out by the rich narrative histories provided by Korstad, Leloudis and Greene.

Durham was unique in a variety of ways. It billed itself as a progressive southern city and was known as the "capital of the black middle class." It was home, at the time, to the North Carolina Mutual Life Insurance Company, the largest black owned financial institution in the country. Durham's black community had also sustained, in the decades leading up to the War on Poverty, strong community based organizations that had engaged in extensive Civil Rights work throughout the period. ${ }^{171}$ Prior to and at the same time as the War on Poverty, members of the black community ${ }^{172}$ engaged in extensive organizing and protest to desegregate schools and public accommodations and end discriminatory hiring policies. In 1963 Wense Graeback, the mayor who would initiate Durham's response to the request for proposals for Community Action in Durham, was elected in the midst of large scale protests, violence and arrests over the desegregation of Howard Johnson's and discriminatory hiring practices. The day after his election saw a demonstration of four to five thousand people, the largest in Durham's history and saw extensive arrests in the wake of that protest. ${ }^{173}$

It was into this tense environment that the North Carolina Fund and federal OEO officials entered when they solicited a proposal for Community Action in Durham. By the time those officials faced a proposal for a Community Action Program in Durham, they were firmly committed to using Community Action as a means to "identify and train leaders from within impoverished neighborhoods, to articulate shared problems and concerns, and to provide the poor with the human and institutional resources necessary to bargain with local political leaders, their employers, and social welfare agencies." Durham's local white leaders, Mayor

\footnotetext{
${ }^{169}$ See infra notes ___ and accompanying text.

${ }^{170}$ See infra notes ___ and accompanying text.

${ }^{171}$ For a detailed discussion of activism in black communities in Durham in the 1940s, 1950s and early 1960s, see Christina Greene, Our SEPARAte Ways: Women and The Black Freedom Movement IN Durham, NORTH CAROLINA 7-104 (2005).

${ }^{172}$ Although this article refers to the black community monolithically for ease of argument, this oversimplifies the story. As Greene describes it there were serious disagreements as to objectives and strategies that often broke down between community members of differing age, class, and gender categories.

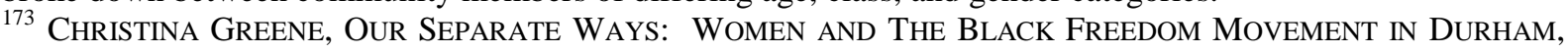
NORTH CAROLINA 88-91 (2005).
} 
Graeback among them, however created a response that attempted not to solicit real participation but instead to contain black protest and black demands. ${ }^{174}$ Graeback appointed a forty seven member commission, consisting for forty four white members and three "token representative" 175 black members, to create a Community Action plan. That group in turn proposed to the Fund the creation of "Operation Breakthrough," a program designed, "to coordinate better services for the indigent and run several experimental education programs." ${ }^{\text {"176 }}$ The commission designed a fairly standard, top down service program that would employ caseworkers to work with families to design "breakthrough plans" to help them move out of poverty. In this sense, the original plans were squarely in line with the social service model that dominated Community Action throughout the country. ${ }^{177}$

Although the Fund gave Operation Breakthrough an initial grant of $\$ 11,000$ in July of 1964, administrators at the Fund and in Washington pushed back on the issue of participation and made clear that, unless the Operation Breakthrough board was racially integrated and included at least one third of its members from low income communities, Operation Breakthrough could not continue. ${ }^{178}$ After extensive negotiations, Operation Breakthrough hired staff to help create neighborhood councils who would elect board members and meet the Fund and OEO's representation requirements. ${ }^{179}$ By December, OEO had authorized an $\$ 181,000$ grant to the organization.

i. The Work of The Neighborhood Councils and It's Effect on The Operation Breakthrough Mission

The neighborhood councils in Durham's black communities, which came into being as a result of pressure to realize the participation mandate, began grassroots organizing campaigns and, over the course of several years, would significantly shift the mission of Operation Breakthrough. ${ }^{180}$ Within a remarkably short period of time an organiation which was

${ }^{174}$ Christina Greene, Our Separate Ways: Women and The Black Freedom Movement in Durham, NORTH CAROLINA 108 (2005).

${ }^{175}$ Christina Greene, Our Separate Ways: Women and The Black Freedom Movement in Durham, NORTH CAROLINA 108 (2005).

${ }^{176}$ Christina Greene, Our Separate Ways: Women and The Black Freedom Movement in Durham, NORTH CAROLINA 108 (2005)

${ }_{177}$ See infra notes ___ and accompanying text.

${ }^{178}$ ROBERT R. KORSTAD \& JAMES L. LELOUdis, TO RIGHT THESE Wrongs: THE NORTH CAROLINA Fund AND THE BATTLE TO END POVERTY AND INEQUALITY IN 1960S AMERICA 178 (2010).

${ }^{179}$ Christina Greene, Our Separate Ways: Women and The Black Freedom Movement in Durham, NORTH CAROLINA 119 (2005). Operation Breakthrough is in fact still in existence in Durham. On its website legacy page, it describes the organization's activities in 1965 as follows: "The Neighborhood Advisory Council was formed as a central delegation to represent the individual neighborhood community councils. One of its responsibilities was the selection of a representative of the low income population to sit on the OBT Board of Directors as required by OEO guidelines." http://www.obtnc.com/legacy.htm (last visited October 25, 2011).

${ }^{180}$ RoBert R. KORSTAD \& JAMES L. LELOUdis, TO RIGHT THESE WRONGS: THE NORTH CAROLINA Fund AND THE BATTLE TO END POVERTY AND INEQUALITY IN 1960S AMERICA 6 (2010). (During this period, the focus 
originally designed to coordinate individually focused services became a significant force for institutional change. Initially organizing focused in black communities. Howard Fuller, who would come to be one of the most controversial figures in fights over the War on Poverty in Durham, ${ }^{181}$ was hired to organize neighborhood councils that would, in turn, elect representatives to the Operation Breakthrough board. The neighborhood councils in black communities grew substantially over the following months and years. In the fall of 1965 there were five; by early 1966 there were seventeen, and by 1968 there were 23 councils with 1,000 members representing 20,000 predominantly low-income black residents of Durham. ${ }^{182}$ Organizing in poor white communities lagged behind. In an effort to address this gap, in 1968, Operation Breakthrough sought a grant from OEO to fund "Experiment in Parallel Organization" an effort to organize poor whites. This grant led to the founding of ACT, a federation of poor whites that would go on to organize an additional 21 neighborhood councils. $^{183}$

The black neighborhood councils focused initially on housing and welfare issues. Durham's low income housing stock was, in some areas "totally dilapidated." In the eyes of one observer the housing looked more like what one would find in a "depressed backward county" than in a modern southern city. Housing had unsound or nonexistent plumbing, streets were unpaved, and some houses lacked electricity. ${ }^{184}$ The conditions of employment and the policies of the welfare department were no better. Workers received low wages and were treated harshly. Neighborhood councils organized around all these issues. Councils supported strikes by school cafeteria workers and Duke's housekeepers and Janitors seeking higher wages and better treatment. They waged campaigns seeking and winning gains in the condition of public housing and the need for the agency to articulate a basis for eviction.

From the perspective of the impact of the neighborhood councils on the mission of Operation Breakthrough it is clear that the Councils drew the mission away from the initial social service model. In the course of their work, Neighborhood councils utilized Operation Breakthrough resources and neighborhood council members served on Operation Breakthrough's board. This would ultimately lead to substantial conflict within the board and, eventually to a conviction among the community organizations that they needed operational and budgetary independence.

would shift, "from civil rights activism to neighborhood organizing, antipoverty agitation, and economic development efforts.").

${ }^{181}$ Robert R. Korstad \& JAMES L. Leloudis, To Right TheSE Wrongs: THE NoRTH CAROLINA Fund AND THE BATTLE TO END POVERTY AND INEQUALITY IN 1960S AMERICA 119 (2010).

${ }^{182}$ Christina Greene, Our Separate Ways: Women and The Black Freedom Movement in Durham, NORTH CAROLINA 117 (2005).

${ }^{183}$ See Christina Green, "Someday ... the Colored and Whtie Will Stand Together" in THE WAR ON POVERTY: A GRASSROOTS HISTORY 164 (2011).

${ }^{184}$ Christina Greene, Our Separate Ways: Women and The Black Freedom Movement in Durham, NORTH CAROLINA 128 (2005). 
ii. Challenging the Scope of Participation: The Emergence of United Organizations for Community Improvement

Ultimately, for reasons of strategy as well as fundamental incompatibility, the Neighborhood Councils agreed to come together as one organization, the United Organizations for Community Improvement (UOCI) and to split off from Operation Breakthrough. ${ }^{185}$ UOCI, then sought separate funding from the Fund, invoking the independent organization strategy supported by OEO and Congress. ${ }^{186}$ At that point Fund and OEO officials faced a dilemma about participation that lay at the heart of administering the Maximum Feasible Participation mandate and that confronted OEO as it struggled over the issue of the role of independent community groups in Community Action. ${ }^{187}$ Was participation limited to diverse representation on the governing board or did the Fund have to move to direct funding of sometimes oppositional community organizations in order to create "maximum feasible" participation? The struggles within the Fund over this decision shed light on the thinking of administrators committed to robust participation and also highlight the limits of this strategy.

Several Fund officials, who had by that point ample experience in watching the ways that mobilization could be co-opted and undermined, argued strongly that organizations like UOCI, which they termed "counter CAPS" ${ }^{188}$ should be funded under the program. In so doing they articulated a rationale that underlay the strategy of achieving participation through the support by OEO of organizations "which display an unusually high degree of involvement of poor persons in their initiation and operation." 189 Supportive fund officials "argued that the establishment of Counters-CAPS such as UOCI ... was the logical next step in a 'spiral of participation' that the Fund had set in motion with its first call for community action proposals." ${ }^{190}$ Ultimately the Fund decided to continue to fund both Operation Breakthrough and UOCI as a means to provide UOCI, ". . . with the resources required to transform itself from a 'crisis-oriented' [organization] into [a] permanently established [agency]." This decision was crucial. It signaled the incorporation of the idea, mirrored in OEO's endorsement, between 1964 and 1967 of funding separate, sometimes oppositional

\footnotetext{
${ }^{185}$ Robert R. Korstad \& JAMES L. Leloudis, To Right TheSE Wrongs: THe North CARolina Fund AND THE BATTLE TO END POVERTY AND INEQUALITY IN 1960s AMERICA 189 (2010).

${ }^{186}$ See infra notes _ and accompanying text. ACT would receive a grant from OEO a bit later, in 1968. ROBERT R. KORSTAD \& JAMES L. LELOUDIS, TO RIGHT THESE WrongS: THE NORTH CAROLINA Fund AND THE BATTLE TO END POVERTY AND INEQUALITY IN 1960S AMERICA 319-20 (2010).

${ }^{187}$ See infra notes __ and accompanying text.

${ }^{188}$ The North Carolina Fund funded what they termed "Counter CAPS" not only in Durham but in the Choanoke region of the state. ROBERT R. KORSTAD \& JAMES L. LEloudis, To Right TheSE WrongS: THE North CAROLINA FUND AND THE BATTLE TO END POVERTY AND INEQUALITY IN 1960S AMERICA 217 (2010).

189 Office of Economic Opportunity EXec. OfF. OF The President, Community Action Program Memo No. 9-A (1967) at 4.

${ }^{190}$ Robert R. Korstad \& JAMES L. Leloudis, To Right TheSE Wrongs: THE North CAROLINA Fund AND THE BATTLE TO END POVERTY AND INEQUALITY IN 1960S AMERICA 219 (2010).
} 
organizations in order to realize robust participation.

UOCI would go on, sometimes in collaboration with Operation Breakthrough and sometimes on their own, to continue to press the issues of their communities. For example, pursuing a strategy of pressure from UOCI from the outside simultaneous with negotiations by Operation Breakthrough inside, they fought and won an effort to bring Head Start to Durham despite white opposition to its integration and antidiscrimination mandates. ${ }^{191}$ UOCI faced perhaps its most difficult battle when Duke University opposed the construction of public housing near campus and the public housing authority simultaneously proposed to build additional housing on property contiguous with segregated poor neighborhoods. UOCI viewed these twin actions as efforts, "to pack the black poor ever more tightly into a "negro ghetto' in the segregated southeastern corner of town." 192 In the face of substantial white opposition that manifested itself in Klan demonstrators facing the protesters, they conducted a peaceful protest campaign and ultimately won some significant concessions. ${ }^{193}$

\section{iii. The Growth of Community Leaders}

In the course of the work of the neighborhood councils and UOCI, community members took on leadership roles and became significant forces in their communities. Low income black women such as Pat Jones Rogers, a founder of the Durham Tenants Steering Committee, Joyce Thorpe, the founder of a housing rights group, Irene Joyner, co-chair of the Tenant's Steering Committee, and Callina Smith, founder of the Durham Welfare Rights Organization, took leadership positions through the work of the neighborhood councils and built a base of power that they wielded, sometimes quite successfully, to address the needs that they defined for their communities. Although extensively retelling the stories these women is well beyond the scope of this article, a few details about the work of two women, Ann Atwater and Joyce Thorpe, demonstrate the extraordinary growth of leadership among black women catalyzed, at least in part, by Community Action.

Ann Atwater met organizers Howard Fuller and Charsie Hedgepeth ${ }^{194}$ in 1965. Atwater was a black woman and daughter of Julia Lucas, a prominent member of the black middle

${ }^{191}$ Robert R. Korstad \& JAMES L. Leloudis, To Right TheSE Wrongs: The North CAROLINA Fund AND THE BATTLE TO END POVERTY AND INEQUALITY IN 1960S AMERICA 189 (2010).

${ }^{192}$ Robert R. Korstad \& JAMES L. LELOUdis, To Right These Wrongs: THE North CAROLINA Fund AND THE BATTLE TO END POVERTY AND INEQUALITY IN 1960S AMERICA 225 (2010).

${ }^{193}$ Robert R. Korstad \& JAMES L. LELOUdis, To Right THESE Wrongs: THE NORTH CAROLINA Fund AND THE BATTLE TO END POVERTY AND INEQUALITY IN 1960S AMERICA 225-29 (2010).

${ }^{194}$ Charsie Hedgepeth came to organizing from a family of prominent black leaders. Her mother was Julia Lucas, who had a long history of leadership in the organizations of the black middle class in Durham. Charsie Hedgepath would also served as the secretary of the Black Solidarity Committee, which held a seven month boycott of Durham's white owned businesses in the late 1960s Christina GREENE, OUR SEPARATE WAYs: Women and The Black FreEdom Movement in Durham, North Carolina 2-3 (2005). 
class. ${ }^{195}$ At the time Ann Atwater was, "surviving on a welfare check for \$57 per month and occasional earnings from domestic work in white homes." 196 When Atwater met Fuller and Hedgepath she was in the midst of struggle with the welfare agency over a rental payment and was living in a home in serious need of repair. Fuller and Hedgepath helped Atwater successfully put pressure on her landlord to make repairs and Atwater quickly joined them in their organizing work. Atwater would go on hold the position of supervisor for neighborhood workers and would head a committee for the soon to be formed United Organizations for Community Improvement. Atwater became well known for her mastery of public housing regulations and her ability to wield them successfully on behalf of her community. ${ }^{197}$ In 2004 she was honored by the NAACP for her service to her community. ${ }^{198}$

Joyce Thorpe, a resident of public housing in Durham, came to prominence in the organizing work of the neighborhood councils as the founder and president on the McDougal Terrace Mothers Club. ${ }^{199}$ As the Supreme Court described the facts in the case concerning her eviction, "[o]n August 10, 1965, [Thorpe] was elected president of a McDougald Terrace tenants' organization called the Parents' Club. On the very next day, without any explanation, the executive director of the Housing Authority notified petitioner that her lease would be canceled as of August 31."200 With the help of Howard Fuller and Civil Rights attorney Floyd McKissick Thorpe's eviction would be stayed, and her case would become a rallying point for neighborhood activism. In the wake of the publicity around the attempted eviction, the public housing authority in Durham, "met with 150 tenants and conceded to a number of demands, including the preparation of a new lease that contained a clause requiring the landlord to provide a reason for eviction." ${ }^{201}$ In addition, in apparent response to litigation filed by Thorpe and others the federal Department of Housing and Urban Development issued a directive, shortly after the commencement of Thorpe's eviction proceeding, mandating that public housing authorities state cause for eviction and provide some level of pre-eviction due process. ${ }^{202}$ Ultimately the litigation filed on Thorpe's behalf by the NAACP would lead to a

\footnotetext{
${ }^{195}$ RoBert R. KORSTAD \& JAMES L. LELOUdis, To Right THESE Wrongs: THE NORTH CAROLINA Fund AND THE BATTLE TO END POVERTY AND INEQUALITY IN 1960S AMERICA 181 (2010).

${ }^{196}$ Robert R. Korstad \& JAMES L. LELOUdis, To Right THESE Wrongs: THE NoRTH CAROLINA Fund AND THE BATTLE TO END POVERTY AND INEQUALITY IN 1960S AMERICA 181 (2010).

${ }^{197}$ Christina Greene, Our Separate Ways: Women and The Black Freedom Movement in Durham, NORTH CAROLINA 115 (2005).

${ }^{198}$ Christina Greene, Our Separate Ways: Women and The Black Freedom Movement in Durham, NORTH CAROLINA 229 (2005).

${ }^{199}$ Christina Greene, Our Separate Ways: Women and The Black Freedom Movement in Durham, NORTH CAROLINA 105 (2005).

${ }^{200}$ Thorpe v. Housing Authority of Durham, 393 U.S. 268, 271 (1969).

201 Christina Greene, Our Separate Ways: Women and The Black Freedom Movement in Durham, NORTH CAROLINA 113 (2005).

${ }^{202}$ Thorpe v. Housing Authority of Durham, 393 U.S. 268, 273 (1969) (HUD Circular entitled "Termination of Tenancy in Low-Rent Projects was issued on February 7, 1976 and stated that, "[w]ithin the past year increasing dissatisfaction has been expressed with eviction practices in public low-rent housing projects. During that period a number of suits have been filed throughout the United States generally challenging the right of a Local
} 
holding by the Supreme Court, that the directive was lawfully issued; that the Durham housing authority was required to comply with the directive, and that the directive applied to Thorpe even though it was issued after the commencement of her eviction. ${ }^{203}$ Thorpe herself stayed housed during the pendency of the case and would go on to become the first female and the first black Physicians Assistant at Duke University. She is known today in Durham as the "mother of the P.A.s.",204

\section{Robust Participation in Durham}

For the purposes of this article the Durham stories told above provide interesting suggestions about both the nature and quality of participation as measured by the definitions of substantive participation offered above. By both measures, substantive participation and political power transfer, the stories confirm the suggestion that participation in Durham was, as Austin suggested, quite robust.

\section{(a) Substantive Participation}

Asking about the quality of substantive participation requires one to ask what effect representation had on the mission and direction of the collaborative governance endeavor. Did the presence of an opportunity for participation result in the ability of the represented community to effect policy in a way that, in their view, was of benefit to them? In Durham this clearly occurred. The participatory opportunity, first complied with through the creation of the neighborhood councils and later through the direct funding of UOCI, created an opportunity for community members to shift the mission of Operation Breakthrough.

Operation Breakthrough began, in the minds of its original framers, as a service coordination and social work driven model. The "breakthrough plan" model reveals this focus, putting the original plans squarely the dominant social service strategy and culture of

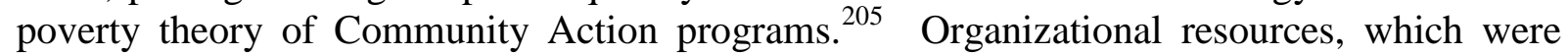
originally directed toward services, supported instead remarkably effective campaigns around substandard housing conditions, arbitrary evictions, unfair employment practices, and discriminatory treatment by the welfare agency. Ann Atwater and others in her community were, due to their organizing efforts, able to get their homes repaired and understand their

Authority to evict a tenant without advising him of the reasons for such eviction. Since this is a federally assisted program, we believe it is essential that no tenant be given notice to vacate without being told by the Local Authority, in a private conference or other appropriate manner, the reasons for the eviction, and given an opportunity to make such reply or explanation as he may wish. In addition to informing the tenant of the reason(s) for any proposed eviction action, from this date each Local Authority shall maintain a written record of every eviction from its federally assisted public housing.

${ }^{203}$ Thorpe v. Housing Authority of Durham, 393 U.S. 268, 274 (1969).

${ }^{204}$ Christina GreEne, OUR SEPARATE WAYs: WoMEN AND THE Black FreEdom MoveMENT IN DURHAM, NORTH CAROLINA 279 n. 18 (2005).

${ }^{205}$ See infra notes ___ and accompanying text. 
housing rights. Joyce Thorpe and her colleagues played a significant role in changing both local and federal public housing policy; Head Start came to Durham with the integration mandate in place; community members changed welfare policies, and the community successfully slowed and altered the further segregation of public housing. Given the extraordinary forces aligned against change, these accomplishments are impressive.

In short, the work of the community organizations exerted a pull on the mission of Operation Breakthrough that led to a reshifting of funding and structure in the organization. In terms of substantive participation, then it appears clear that the UOCI and the neighborhood councils members had and wielded the power to direct the resources of Community Action toward the issues they considered crucial and the strategies they considered effective. ${ }^{206}$

\section{(b) Political Power Transfer}

The second measure of robust participation proposed above focuses on political power transfer. It asks whether there is evidence that, as a result of the participatory opportunity, poor communities gained some measure of additional political power. There is no question that this took place in Durham. As Korstad and Leloudis describe it:

. . . instead of calming unrest, Operation Breakthrough was mobilizing a stratum of the black community that had been largely on the sidelines of the youth- and churchled protests of the early 1960s. An army of the 'organized and articulate poor' was in the making. . . . They were 'people long kicked down' who were not determined to steer the War on Poverty along a radically democratic course that at the outset its generals, 'had only dimly perceived.'

As noted above, between 1965 and 1970, 23 neighborhood councils in black communities and 21 neighborhood councils in white communities and two major new community organizations, UOCI and ACT, were founded. Poor people like Joyce Thorpe and Ann Atwater, took hold of those organizations, became community leaders and went on to a long life of making a significant positive impact in their communities. The campaigns and victories described above arose from organizing work conducted by Operation Breakthrough and UOCI staff and members. And, as Howard Fuller succinctly described it, "a redistribution of power" ${ }^{207}$ took place.

D. The Conditions Under Which Robust Participation Flourished: Some Lessons From North Carolina and Beyond

The stories above are, in a sense, not primarily stories about the mechanisms of

${ }^{206}$ See infra notes __ and accompanying text.

${ }^{207}$ Christina Greene, Our SeParate Ways: Women and The Black Freedom Movement in Durham, NORTH CAROLINA 137 (2005). 
Community Action. It is certainly true, as Marris and Rein ${ }^{208}$ suggest, that much of the activism of the period would have occurred without Community Action. But is also true, that in places like Durham the presence of the North Carolina Fund and OEO and their collective willingness to be pushed toward robust forms of participation provided key leverage for communities. In this sense, the North Carolina story suggests some lessons about the conditions under which robust participation is more likely to arise.

1. The Role of Participatory Mandates, Administrative Flexibility and Strategic Advocacy

There can be little question that the presence of the participation mandate within Community Action was a crucial tool to realize robust participation in Durham, both for the administrators who enforced it and for the advocates who attempted to leverage it to support their organizations. The basic statutory mandate to conduct programs with "maximum feasible participation" created opportunities for both committed administrators and community activists. This was clear in several instances. The one third board participation requirement provided a tool that the North Carolina Fund and OEO administrators were able to wield to force the issue of participation on a reluctant Operation Breakthrough board. It also created a wedge by which the administrators forced the creation of the community based organizations that would ultimately become UOCI. As detailed above, although OEO and Congress would both ultimately back away from the more radical manifestations of this policy, for a time they employed this strategy across the nation explicitly as a means to augment participation. ${ }^{209}$

While it is true that the clear baseline rule that participation must be included was crucial, administrative discretion was also essential in North Carolina and beyond. For example, it created an opening for UOCI to press the North Carolina Fund to move towards more robust political power transfer in their definition of participation. This dynamic became clear as the Fund responded to pressure from UOCI and other similar community coalitions to fund "counter-CAPS." This flexibility was mirrored on the federal level through the numerous means by which OEO was clearly willing to consider realizing participation. ${ }^{210}$ Had OEO and the Fund been committed to realizing participation solely through board membership, the level of robust participation that occurred would likely never have happened.

Beyond Durham, it is clear that, between 1964 and 1967, OEO was committed both to baseline representation on governing board and to the use of multiple strategies to realize maximum feasible participation. ${ }^{211}$ Shriver, in a September 1966 memo reaffirming the

\footnotetext{
208 PETER MARris \& MARTIN REIN, DILEMMAS OF SOCIAL REFORM: POVERTY AND COMMUNITY ACTION IN THE UNITED STATES 269 (1973).

${ }^{209}$ See infra notes ___ and accompanying text.

${ }^{210}$ See infra notes ___ and accompanying text.

211 See infra notes___ and accompanying text describing the multiple strategies available to CAAs to realize
} 
agency's commitment to participation, defended the decision to remain flexible and cautioned localities not to mistake this for a lack of commitment to realizing robust participation. As he stated it,

Our refusal to be bound by strict formulas or uniform applications of the principle of “maximum feasible participation' must not be interpreted as softness on the principle itself. While we accept flexibility in the implementation of such participation, we are inflexible in our determination to achieve it as fully and as rapidly as possible. ${ }^{212}$

And in fact, on the whole, one of them most effective strategies for realizing robust participation in retrospect was the willingness of administrators to allow local communities to innovate in the area of participation. The Durham story and others like it suggest that their willingness to fund separate organizations in multiple forms, while enormously controversial, ${ }^{213}$ was also particularly effective in enabling communities both to exert control and to build political power. It is certainly true, as Austin and Greenstone and Peterson's studies reveal, that not every location had the underlying socio-political context necessary to yield organizations ready to take advantage of that opportunity. Nevertheless, the willingness of administrators to enforce a baseline but then employ multiple tools to realize the mandate seemed to correlate with expanding possibilities for robust participation.

2. The Importance of Community Organizations in Realizing Robust Substantive Participation

As detailed above, OEO's Community Action Program guide embraced three distinct structures for realizing maximum feasible participation: membership on the governing board, various forms additional community input in design and implementation, and the funding of independent organizations. ${ }^{214}$ In the Operation Breakthrough stories highlighted above, it is clear that the third strategy yielded significant results in terms of robust participation both in terms of the overall control that the community exerted over the direction of Operation Breakthrough and the opportunities for political power transfer that arose as a result of Community Action. The significant role of organizations, both in the form of neighborhood councils and later in the creation and work of UOCI, created space for the black community to exert programmatic control and support leadership development in their community. The extraordinary growth in neighborhood councils, the work of UOCI and the growth of leaders like Ann Atwater and Joyce Thorpe are testament to the way in which funding of these autonomous agencies was an effective means to use a participatory mandate to achieve robust substantive participation and political power transfer.

maximum feasible participation.

${ }^{212}$ Office of Economic Opportunity Exec. OfF. of The President, Community Action Program Memo No. 49 (1966) 2.

${ }^{213}$ See infra notes __ and accompanying text.

${ }^{214}$ See infra notes ___ and accompanying text. 
Additional research from the period suggests that not only does support of community organizations lead to strong organizations that have power but strong organizations also play a crucial role in the strength of representatives inside the collaborative governance endeavor. ${ }^{215}$ The study conducted by Greenstone and Peterson identifies a crucial link between organizational strength and the quality of substantive representation that elected or appointed representatives provided on Community Action Boards. In their study of participation in five cities, Greenstone and Peterson found that the most effective representatives, in terms of the degree of substantive representation on the governing board combined two attributes: organizational skills, and socially descriptive representation (meaning that they were similar to neighborhood representatives in socially relevant ways - in this case race and class). In describing the often very effective skills of those representatives, Greenstone and Peterson note that, in cases where individuals were ineffective, it was due primarily to lack of, "familiarity with complex bureaucratic organizations [needed] to operate skillfully in pursuing their goals." ${ }^{216}$ When individual representatives had an organizing background and the skills and perspective that accompany that background, they were often more successful than their non-socially descriptive counterparts. As Greenstone and Peterson explain it, the more socially descriptive representatives were often less likely to be, "taken in by middle-class political tactics." 217

In discussing why organizational backing correlated, in their study, with more robust substantive representation, Greenstone and Peterson explain that, representatives appointed by community organizations drew strength in terms of substantive participation in two interrelated ways. First, as representatives of the organization they could call on the strength of those organizations to back their positions. This seems clearly to have been occurring in Durham as the community organizations pulled the agenda and resources of Operation Breakthrough away from the service model and towards a more activist set of interventions. In addition, and crucially, these particular representatives were not only backed by but were accountable to those organizations. This accountability correlated in turn with a higher level of commitment to community wide, as opposed to patronage focused, gains by those representatives. So in sum in Greenstone and Peterson's analysis if the goal is robust substantive participation, i.e., significant community control by representatives that serve the interests of their communities, then, as they concluded, "[t]he most important source of control may be an arrangement for selecting representatives that provides substantial influence for organized groups committed to universalistic interests." 218

215 J. David Greenstone and Paul E. Peterson, Race and Authority in Urban Politics: Community PARTICIPATION AND THE WAR ON POVERTY (1976).

${ }^{216}$ J. DAVid Greenstone and PaUl E. Peterson, Race AND Authority in Urban Politics: Community PARTICIPATION AND THE WAR ON POVERTY 188 (1976).

${ }^{217}$ J. David Greenstone and Paul E. Peterson, Race and Authority in Urban Politics: Community PARTICIPATION AND THE WAR ON POVERTY 188 (1976).

${ }^{218}$ J. David Greenstone and Paul E. Peterson, Race AND Authority in Urban Politics: Community PARTICIPATION AND THE WAR ON POVERTY 198 (1976). Greenstone and Peterson also note the corollary to this 


\section{A Strategic Right to Participation: Some Possibilities, Implications and Areas for Further Research}

In the final analysis the foregoing discussion suggests a few crucial answers to how policy makers, administrators and activists might each work to render participatory governance endeavors more robust. The first lesson has to do with the role of legal structures and administrative discretion and the second focuses on the limits of tokenism and the crucial role played by community organizations.

\section{A. Law, Rights and Administrative Discretion}

Although the focus of this paper has been largely on the role of organizations and organizing in rendering substantive participatory rights, it is crucial not to forget that the legal structure mandating and implementing participation played a crucial role. Were it not for the statutory inclusion of the mandate for maximum feasible participation and the mandate, first administrative and then for a time statutory, that one third of the CAA boards must include community representatives, community participation might not have occurred. Clearly the statutory mandate that the program be conducted with the "maximum feasible participation" of the poor provided a crucial rule for administrators to enforce and a crucial hook around which communities could organize and advocate.

Administrative discretion was also important. The extensive flexibility displayed by OEO in defining the means to reach participation and the ability of the North Carolina fund to choose to fund UOCI as a "counter cap" and, on a larger scale, the repeated willingness of OEO officials between 1964 and 1976 to employ multiple means to reach maximum feasible participation, ${ }^{219}$ made an enormous difference. In the North Carolina story, it allowed a porousness within the administrative entity for effective advocacy by community representatives. And across the nation, for communities that were equipped to do so, it provided a crucial mechanism to implement in continuing to fight for racial and economic justice. If OEO and the North Carolina Fund had defined maximum feasible participation as entirely satisfied by percentages of funding and representation, much of this strategic wielding of Community Action might never have taken place.

finding. Representatives in Philadelphia and Los Angeles, who were generally elected to their position on the CAA governing board in fairly lightly contested neighborhood "poverty elections" as opposed to being nominated by community based organizations, tended to exert little power or influence in the governing body and tended to be more likely to focus on patronage related as opposed to community-wide gains. Greenstone and Peterson attribute the relative less robust character of the substantive representation to the low stakes nature of those particular poverty elections. Due primarily to the lack of, the "elections"

${ }^{219}$ See infra notes __ and accompanying text. 


\section{B. Organizational Strength and Tokenism}

Perhaps the most striking suggestion from the history detailed in this paper is the overwhelming difference that strong organizations made to whether or not participation was robust. In Durham and likely beyond, when organizations built strength in community both those organizations and their representatives on the governing boards garnered and wielded power. This suggests some very important lessons for those interested in participatory democracy.

First and most basically, in contexts such as poverty policy, where stakeholders from poor communities often wield far less power than service providers, this history supports current suggestions in the literature that, in situations of disproportionate power, procedural rules focusing on ensuring representation of stakeholders on governing boards seem unlikely, no matter how carefully drafted, to result in robust participation on their own. ${ }^{220}$ Austin's finding that in all twenty of the cities he studied $1 / 3$ of the governing board were representatives of "residents of affected communities" along with his finding that, by and large, representatives wielded very little power, certainly provides some strength to that argument. Second, this history suggests that tokenistic representation, putting for example an unaffiliated poor person on a board, or even putting a few, will not result in robust substantive representation. The tokenism evidenced in the initial Operation Breakthrough board, Greenstone and Peterson's finding that substantive representation was far more robust when representatives were nominated by, representative of and accountable to community based organizations, the evident strength aligned in favor of community needs by UOCI, and UOCI's clear impact on the mission of Operation Breakthrough make this evident. Tokenistic representation may salve the conscience of those organizing the governance endeavor, but it is unlikely to lead on its own to anything more. The stories here suggest that one path for those dedicated to creating opportunities for robust substantive representation inside collaborative governance endeavors may be found in thinking seriously about returning to OEO's strategy of funding independent community controlled organizations.

\section{The Implications for New Governance}

A purported central benefit of new governance structures is that it has the potential to "further democracy significantly more than traditional electoral means."221 This article has posited that one potential positive outcome of a program that includes participatory democratic structures is the possibility that it might result, for subordinated communities, in robust participation: an enhanced ability of subordinated communities to steer programs toward their needs and a means to garner additional political power for subordinated communities. To the extent that these two purported benefits overlap, the history of Maximum Feasible Participation and Community Action as told in this article provides a

\footnotetext{
${ }^{220}$ See infra notes ___ and accompanying text

${ }^{221}$ William H. Simon, New Governance Anxieties: A Deweyan Response, 2010 WISC. L. REV. 727, 730.
} 
weighty historical counterpoint to the realization of this goal within current new governance and poverty initiatives. Some of these programs, notably the Department of Housing and Urban Development's regulations mandating resident participation in public housing ${ }^{222}$ and the Workforce Investment Act's mandates concerning participation in their governing boards, ${ }^{223}$ do, like Community Action, require participation of affected communities on governing boards. However, neither of these programs go further, as did the architects of and advocates within Community Action, ${ }^{224}$ towards the support of independent organizations as a means to augment participation. As argued above, it was quite evident that in jurisdictions where the focus was entirely on participation on the CAP board and not on support of organizations on the outside, participation did not tend to be robust. This history suggests that it is crucial to ask whether current structures that focus only on participation inside a governing structure may be equally ineffective. The history also suggests that other new governing structures, notably New York City's Center for Economic Opportunity and the Obama administration's Social Innovation Fund, go even less far and are even less likely to result in robust participation. New York City's initiative was originally launched by a committee that had broad representation from various sectors but not representation from poor communities themselves. And the Social Innnovation Fund has no such structure, either in its inception or in its ongoing operation. In short, these programs embrace experimentalism but not participatory democracy. While there may well be significant benefits that come from this experimentation, any claims it makes to deepen democracy rings quite hollow.

In the final analysis, this history suggests that, if it is in fact the case that new governance is to have a role in poverty policy and is to promote, democracy, new governance programs in the poverty field would have to be quite radically restructured. As suggested above, not only should new governance structures ensure the existence of a significant participatory mandate but they must allow for additional means, including the funding and support of autonomous community controlled organizations, to augment and support participation.

D. The Implications for Poverty Law

This article began by invoking Scott Cummings conception of "constrained legalism," the idea that lawyers working with and on behalf of politically marginalized communities strategically employ the law while understanding its limits. As an initial matter, the stories in this article reflect Cummings' broad frame. Although law and legal structures were crucial during the War on Poverty, they had little capacity to spur change on their own. It was in the political sphere, in the interactions between law, administration and organizational advocacy, that change occurred.

From a position of constrained legalism, it is perhaps useful to revisit the question of

\footnotetext{
${ }^{222}$ See infra notes __ and accompanying text.

${ }_{223}^{223}$ See infra notes __ and accompanying text.

${ }^{224}$ See infra notes __ and accompanying text.
} 
the utility of current governance structures to communities. Whether or not experimentalism, or social innovation, as currently structured, promotes democracy, it remains true that social innovation and new governance are both significant, related and growing phenomena in the New Poverty Agenda and beyond. ${ }^{225}$ It is also true that some of these structures nod, however weakly, towards participatory democracy. Turning to the history, if one accepts the findings of Austin, Marris and Rein, that, in the majority of circumstances Community Action and Maximum Feasible Participation were, like today's programs, similarly weak and ineffective at promoting democracy, this lends, perhaps a glimmer of hope. It is important to remember that it was only in the hands of activist communities and sympathetic administrators that, in particular locations, communities were able to seize the mechanisms of Community Action and wield them in a way that resulted in robust participation. Today, lawyers working in the field of poverty law, and in particular those dedicated to continue to work in the mode of "community lawyering",226 might look to this history to add to what is quite clearly a beleaguered tool box. ${ }^{227}$ Advocates and communities might explore whether there might be strategic opportunities, such as those that existed in the past, for seizing these governing structures to serve the ends of affected communities. For example, lawyers and activists might argue that Obama administration's social innovation fund and New York City's Office of Economic Opportunity include organizational representatives on its evaluative boards and mobilization within its funding portfolios. They might argue for more robust organizational support within public housing rights to representation. They might work with communities to reject offers of tokenistic representation, such as those on the Workforce Investment Act boards, and push towards more robust organizational structures.

Each of these possibilities and others like them merit far more detailed consideration. They are offered here simply to suggest possible strategies to explore. Thinking seriously, as did our predecessors, about how to use the legal structures of experimentalism and participation to benefit poor communities might not only yield some substantive benefit in terms of the direction of resources committed to addressing poverty. It might also take a lesson from history and reignite conversations about the ability of legal and administrative structures to deepen participatory democracy.

\footnotetext{
225 See also Wendy A. Bach Governance, Accountability and the New Poverty Agenda 2010 WISC L. REV. 239.

${ }^{226}$ For a discussion of Community Lawyering see infra $\mathrm{n}$.

227 This is not to suggest, in any way, that advocates should abandon rights for experimentalism. It is clearly important to continue to defend, ${ }^{227}$ wield $^{227}$ and, reinvent ${ }^{227}$ whatever post Goldberg and King substantive and procedural rights remain. That work continues to provide essential protection to client and classes of affected individuals and provides a bulwark against some of the harshest policies affecting those who need those programs to survive. See infra notes and accompanying text.
} 